\title{
Capital Access Bonds: \\ Contingent Capital with an Option to Convert ${ }^{1}$
}

\author{
by \\ Patrick Bolton \\ Columbia University
}

and

Frederic Samama

SWF Research Initiative

Amundi - Credit Agricole Group

September 2010 - Revised September 2011

\begin{abstract}
This paper argues that there is a Coasean Bargain available to banks, Long-term Investors, and Bank Regulators around a particular form of "Contingent Capital". By purchasing rights to issue equity in crisis events at a pre-specified price from Long-term Investors, banks can ensure that they will have sufficient regulatory capital available when they need it most: in a crisis. By selling these rights (effectively, a form of crisis insurance) long-term investors can monetize their counter-cyclical investments strategies in banks and, thus, obtain an adequate return as long-term investors. Bank Regulators, in turn, gain as they can thereby implement a more efficient form of equity-capital regulation. Banks have a special need to maintain their equity-capital base in the event of a crisis. Sovereign Wealth Funds and other long-term investors have proved to be the only available counterparties for banks in crisis times. This is why we argue that these investors must be able to monetize the countercyclical asset-management strategies they are trying to implement by obtaining a higher return on their cash reserves. The form of contingent capital we propose (Capital Access Bond) reflects a balance between investors' preferences, issuers' constraints, and regulators' objectives.
\end{abstract}

1 We thank the editors of Economic Policy and three referees for their helpful comments. We are grateful to Pierre Lepicard, Philippe Henrotte, Pedro Ferreira, Paul Pfleiderer, Tano Santos, Suresh Sundaresan and Zhenyu Wang for many helpful comments. We especially thank Elina Berrebi, Kambiz Mohkam and Louis van Roosendaal for excellent research assistance and also Clement Boisson. The views expressed in this paper are those of the authors and do not necessarily reflect the position of the Credit Agricole Group. Previous drafts of this paper have been circulated under the titles "Contingent Capital and LongTerm Investors: A Natural Match?” (2010) and "Capital Access Bonds: Securities Implementing Counter-Cyclical Investment Strategies" (2011) 


\section{I] INTRODUCTION}

The financial crisis of 2007-2008 has painfully revealed a major weak link in the financial system: excess leverage at many of the major financial institutions. The very high leverage ratios of Bear Stearns, Lehman Brothers, and others as they entered the crisis, put them at risk of bankruptcy even in the event of relatively moderate shocks to their earnings or the value of their assets. Moreover, by putting themselves at risk these institutions also exposed the entire financial system to failure. It is not surprising therefore that a key concern of financial regulatory reform has so far been to make sure that banks are well capitalized. However, while improving banks' resilience in a future crisis, higher equity-capital requirements also raise the cost of capital for banks (at least in the short run) and increase the risk of a credit crunch (Bernanke and Lown, 1991), that is, a significant deceleration in the expansion of credit, with the risk of choking off a recovery and prolonging the current recession.

A second key concern of regulators has been to reduce the risk of another round of bailouts in a future crisis. If ex-ante deleveraging by banks is not sufficient to avoid bank failures in another crisis, then ex-post deleveraging through debt restructuring should be facilitated. One way of easily achieving such ex-post deleveraging is to require banks to hold debt instruments that convert into equity in the event of a crisis, or in the event that an institution approaches a dangerous leverage ratio. This mechanism generally comes under the name of contingent capital or CoCos. Different versions of contingent capital have been proposed (see e.g. Flannery, 2002, 2009, Raviv, 2004, Duffie, 2009, McDonald, 2009, Albul, Jaffee, and Tchistyi, 2010, Pennacchi, Vermaelen and Wolff, 2010, the Squam Lake Report, 2010, Coffee, 2010, Glasserman and Nouri, 2010, and Calomiris and Herring, 2011), but the basic idea underlying these proposals is to put in place a mechanism that more or less automatically reduces leverage by implementing a debt-equity swap akin to a debt restructuring in bankruptcy. One proposed way of implementing such a mechanism is to require that banks issue subordinated debentures, which automatically convert into equity in the event that the bank's leverage hits a pre-specified upper bound or, under other variants, when the bank's stock price hits a pre-specified floor. 
There are already several precedents for this type of financial contract. One example is the contingent capital contract between the Royal Bank of Canada and Swiss Re (see Culp, 2009). ${ }^{2}$ A second example is trustissued contingent capital, a form of funding monoline insurers often relied on before the crisis (see Culp, 2009). ${ }^{3}$

A third set of examples is the contingent capital issues by several banks following the crisis, including Lloyds, the Royal Bank of Scotland (RBS), Rabobank and Credit Suisse. ${ }^{4}$ However, it is fair to say that besides Credit Suisse's CoCo emission, the market for contingent capital has so far been limited and falls well short of the $\$ 1$ trillion banks ${ }^{5}$ in the United States and in Europe will need to raise in replacement of outstanding subordinated and hybrid debt that will be phased out by $2022 .{ }^{6}$ Indeed the new Basel III directives will not allow these forms of debt to count towards regulatory capital anymore and it could well be that contingent capital becomes one of the main alternatives. ${ }^{7}$

As some commentators have been quick to point out, however, contingent capital instruments with automatic conversion triggers of debt into equity have potentially important design flaws, as they may be vulnerable to manipulation, and they may support multiple self-fulfilling conversion equilibria, which generate endogenous volatility and valuation uncertainty (Sundaresan and Wang, 2010).

In this paper we propose another, more flexible, design of contingent capital that all but eliminates the problems created by automatic triggers. Under our contingent capital mechanism banks would simply purchase a (collateralized) option to issue new equity at a pre-specified strike price ${ }^{8}$. Far from being a minor technical fix, this contingent capital mechanism reflects a fundamentally different analysis of the economic

2 Swiss Re committed to purchase preferred stock conditional on the Royal Bank of Canada incurring pre-specified exceptional credit losses. The Royal Bank of Canada's explicit intent with this contract was to limit the amount in loan-loss reserves it needed to hold.

3 A special purpose entity (SPE) on one side issued securities to investors and invested the proceeds in low-risk assets serving as collateral, and on the other side wrote put options to a monoline, giving it the right to issue new capital securities. As long as the option remained unexercised investors received the interest on the collateral and the put-option premium. When, however, the monoline exercised its option, investors ended up holding the newly issued monoline equity.

4 First, in November 2009, Lloyds issued $f_{1} 7.5$ bn of Enhanced Capital Notes (ECN). The ECN are subordinated debt (Lower Tier 2 capital) of fixed maturities ranging from 10-15 years that are convertible by Lloyds into common stock if Lloyds' core Tier 1 capital ratio falls below 5\%. A second scheme gives RBS access to recapitalization by the UK Treasury should its core Tier 1 capital ratio fall below 5\%. In return for this commitment RBS is paying the UK Treasury a $4 \%$ annual premium. Third, Rabobank has issued a contingent capital instrument on the $12^{\text {th }}$ of March 2010 such that investors face a 75\% automatic haircut in the event that the bank's Tier 1 capital ratio falls below 7\%. Finally, Credit Suisse has issued contingent capital notes on the $17^{\text {th }}$ of February 2011, which convert into equity if its risk-based capital ratio falls below $7 \%$.

${ }^{5}$ Interestingly S\&P predicts a similar figure of $\$ 1$ trillion of CoCos which should be needed to fund banks' needs in the coming years. Himmelberg et al. (2011) also provides an estimate for the potential issuance of loss-absorbing securities issuance by banks in the next decade between $\$ 926$ billion and $\$ 1.9$ trillion, for the US market.

${ }^{6}$ This is a huge amount, even compared with the $\$ 35.5$ trillion aggregate market capitalizations of the stock exchanges of these areas.

${ }^{7}$ Furthermore in Switzerland Contingent Capital is the only other form of capital besides common equity that will count towards regulatory capital

8 And what is true for banks could also be true for other companies. 
purpose of contingent capital. It is not just conceived as a somewhat blunt substitute for a bankruptcy (or debt resolution) procedure, but mainly as a capital line commitment for banks, or in other words, a form of insurance against adverse changes in equity markets, for banks who expect to need to raise equity capital in a crisis. We argue that such a capital line commitment can substantially lower the costs of holding an equity capital buffer for banks, as it allows banks to only raise costly equity capital when they need it. ${ }^{9}$ Moreover, this form of contingent capital provides a simple and remunerative way for long-term investors to implement counter-cyclical equity investment strategies, whereby they increase their weighting in a stock when its price is below trend.

Interestingly, this type of investment is similar to one already profitably implemented on a large scale by the legendary long-term investment fund Berkshire Hathaway, who is selling insurance against sharp market downturns in the form of long-term index put options. Indeed, Berkshire Hathaway disclosed writing substantial amounts of equity-index put options on four major indices (S\&P 500, FTSE 100, Euro Stoxx 50, and Nikkei 225) for periods lasting up to a decade. ${ }^{10}$ These options are in principle available to any investor seeking to hedge its long-term exposure to these indices and serve the same purpose as the put options on bank equity described above.

One concern with the types of put options written by Berkshire Hathaway is that the buyer of such options exposes itself to both market risk and counterparty risk. In the case of Berkshire Hathaway counterparty risk concerns are mitigated by the large pool of cash that it holds and by Warren Buffett's reputation. The typical writer of puts, however, has to be able to reassure buyers about counterparty risk and cannot rely on such a stellar reputation as Berkshire Hathaway. Our main proposal is thus to deal with this counterparty risk by collateralizing the put with cash. This can be done straightforwardly by letting the bank issue a "reverse" convertible bond, whereby the issuer rather than the investor gets to decide

9 An early proposal that is close in spirit to ours by Kashyap, Rajan and Stein (2008) is to allow banks to purchase capital insurance from non-bank counterparties. They suggest that the trigger for the insurance payment be based on a "systemic" event, and recommend that counterparty risk be eliminated by requiring the insurer to post collateral invested in Treasuries. The key differences of their proposal relative to ours is in the choice of the automatic "systemic" trigger they favor and in the potentially more complex pricing problems posed by this solution.

10 Berkshire Hathaway discloses in its annual reports of $2007,2008,2009$, and 2010 positions in excess of $\$ 37.1 \mathrm{bn}$ and premium revenues of $\$ 4.9 \mathrm{bn}$. Furthermore, Warren Buffett argues in the report that these options were mispriced at inception, as they were based on theoretical models that did not reflect plausible movements in major market indices. For example, he highlights that if Berkshire sells a 100- year $\$ 1$ billion put option on the S\&P 500 at a strike price of 903 (the index's level on 12/31/08) and if one assumes a possible crash in the index of $100 \%$ with a probability of $1 \%$ over a one-hundred-year period, then the borrowing cost to cover Berkshire's loss in this event on its put options would come to only $6.2 \%$. 
whether to convert the bond into equity. By issuing such a bond the bank effectively gets the investors in contingent capital to "assign" upfront the cash necessary to purchase the equity. We underscore the nature of this instrument as an equity capital commitment for the issuer by referring to it as a Capital Access Bond or $C A B$.

In the remainder of the paper we begin with by setting the analysis of CABs in the broader context of recent debates on the optimal design of bank equity capital regulation in Section II. We then describe in greater detail how our proposed contingent capital contract might be structured in Section III, and how it can both help banks hedge their equity-market risks, provide a high return to long-term investors and implement regulators' objectives in Section IV. We then compare our contingent capital contract to the other recent proposals and discuss in what respect our approach may avoid some of the instability problems of other contingent capital solutions in Section V. Finally, we discuss some refinements and other issues in Section VI.

\section{II] CONTINGENT OR STRAIGHT EQUITY CAPITAL?}

There has been considerable debate recently on the appropriate level and form of bank regulatory equity capital. Prominent commentators, in particular, Admati, DeMarzo, Hellwig and Pfleiderer (2011), Greenspan (2010), and Kashyap, Stein and Hanson (2010), have called for minimum capital requirements (book equity to asset ratios) in excess of $14 \%$, far higher than the current minimum requirements under Basel III. Undoubtedly, such high ratios will go a long way in protecting bank regulators against future bailouts. Corrective action in poorly performing or troubled banks will occur more promptly, and the equity capital cushion is more likely to be sufficient to cover bank losses when intervention occurs, without requiring further bailouts or bailins. Such high levels of equity capital would clearly provide an important benefit in terms of greater financial stability. There is little disagreement about this benefit. The debate is more about the costs of such high equity capital requirements.

Banks argue that it will become much more difficult to meet the return on equity (ROE) demanded by shareholders with such high capital requirements and that as a result a significant credit crunch may be caused by such a sharp increase in required capital (e.g. Ackermann, 2010). There has been considerable 
debate and confusion around this assertion. As Admati et al. (2011) and others have pointed out, under classical Modigliani and Miller perfect capital markets reasoning the required ROE should be lower when bank leverage is lowered, as bank equity is then less risky. Kashyap, Stein and Hanson (2010) also argue that even when one accounts for the tax deductibility of interest payments, an increase in required equity capital only translates into a small increase in banks' weighted average cost of capital (WACC). ${ }^{11}$ By these analyses it is difficult to understand why there has been such resistance by banks to the proposed sharp increases in regulatory capital.

But, as Stein (2010) notes, "this calculation comes with a number of caveats. First, and perhaps most important, it should be thought of as capturing the long-run steady-state costs of having to hold more equity on the balance sheet, while disregarding the transitional flow costs associated with raising the required new equity. Given the adverse selection problems associated with new equity issues (Myers and Majluf, 1984), these flow costs may be significant." There is indeed a very large empirical literature in corporate finance that finds large costs of issuing new equity over and above the classical WACC (see, e.g. the surveys by Eckbo, Masulis and Norli (2007) and Ritter (2003). These costs comprise, the underwriter's fees, the under-pricing of the equity issue, and the negative stock price reaction to the announcement of a new issue (the Myers and Majluf (1984) dilution costs). Some early estimates of the total fixed cost of a new equity issue exceed $21 \%$ of the market value of the new issue for firm commitment offers, and 31\% for best efforts offers (see Ritter, 1987). Estimates for more recent issues are somewhat lower, but they remain very large, so much so that corporations very rarely choose to tap equity markets with new issues (see again Ritter, 2003). ${ }^{12}$

Admati et al. (2011) do not deny that these dilution costs of equity exist, but argue that "While information asymmetry might make the issuance of equity more costly, it does not follow that this is a valid reason to allow high leverage and to argue against higher equity requirements. First, equity issuance is less needed and is less costly when banks use less debt financing on an ongoing basis, such as would be

\footnotetext{
11 In their estimate a percentage point increase in equity capital only raises WACC by 2.45 basis points when one takes the coupon on long-term debt to be $7 \%$.

12 The estimates underlying our ROE assumptions taken from Calomiris and Himmelberg, (1997), are between 2\% to 6\% of the market value of a new issue for investment banking fees, plus another $10 \%$ in under-pricing of an issue, and finally another $2 \%$ of the total equity value lost in the negative price reaction from the issue.
} 
the case if equity requirements were significantly higher. In that case retained earnings, which do not entail issuance costs and which will be more plentiful with lower debt service requirements, can be used to maintain or even grow banks' operations. Second, regulators can mitigate issue costs associated with asymmetric information by removing banks' discretion over payout and issuance decisions." These could well prove to be true observations, but in the absence of any solid empirical evidence they remain largely speculative. Note, in particular, that although, equity holders face lower risk when the bank is less levered, dilution costs (due to balance sheet opaqueness ${ }^{13}$ ) from new equity issues could be just as high as when the bank has higher leverage. ${ }^{14}$ In addition, a dividend cut or a reduction in payout, also comes with a substantial negative impact on equity value, as a large corporate finance literature on dividends has established (see Allen and Michaely, 2003). Finally, removing discretion over payout and issuance decisions is unlikely to significantly reduce information dilution costs, as investors will continue to worry about the quality of the claims they are holding or purchasing. What is more, it is not entirely clear how discretion over equity issuance can be removed. A bank can always refuse to issue new equity and simply comply with the higher equity requirements by selling assets. It is far from obvious how regulators could stop such compliance through such asset sales.

All in all, the existing evidence shows that there are significant costs of issuing equity over and above the Modigliani and Miller risk-adjusted required ROE. Even if these costs can be brought down through such regulatory intervention as suggested by Admati et al. (20011), they will remain significant. Because of these costs we show in this paper that there are efficiency gains from allowing banks to rely at least in part on contingent capital financing to meet their prudential regulatory requirements, as in the case currently under the new bank regulatory regime in Switzerland. We focus our discussion on CABs, which do not have some of the design flaws of other contingent capital instruments, but our analysis of the benefits of contingent capital applies more broadly to other existing contingent capital instruments. There are three major advantages of contingent capital over straight equity capital. First, by purchasing a capital line commitment—a form of insurance policy-banks can guarantee that they will have the required capital when it is needed. As Bolton, Santos and Scheinkman (2011) show, such an ex-ante

\footnotetext{
13 Note also that banks' balance sheets in 2007-2008 were so opaque that even the biggest losers appeared to have sufficient regulatory capital. See Haldane (2011).

14 Indeed, in Myers and Majluf's (1984) article equity dilution costs of new equity issues are derived for an all equity firm.
} 
capital line commitment dominates a straight equity buffer, if the economy is composed of two investor clienteles, short-term investors and long-term investors. In our quantitative analysis of CABs in section III we do not build in the full formal model of Bolton et al. (2011), but the basic argument is the same: CABs improve the payoffs of both long-term investors, who get to implement a counter-cyclical investment strategy, and banks' payoffs, as banks are then able to originate a higher volume of profitable loans with the same equity-capital base. In other words, CABs allow banks to avoid paying the extra cost of an equity issue with probability one. By purchasing a commitment to issue new equity when it is needed, they are able to lower the probability that they will pay this cost. At the same time, long-term investors get to extract an insurance premium for implementing their counter-cyclical investment strategy (that is, for writing a put warrant on the bank's equity). As Bolton et al. (2011) show, the gains from trade arise from the fact that long-term investors have a lower cost in shouldering the burden of supplying equity capital in a crisis. As long-term investors they are natural providers of insurance and can extract an insurance premium. By requiring banks to hold an equity buffer, regulators are in effect denying banks' access to capital insurance, a more efficient risk-sharing contract.

A second, more subtle, advantage of CABs also highlighted in Bolton et al. (2011) is that by setting a (strike) price for a contingent equity-issue long in advance the issuer can reduce equity dilution costs à la Myers and Majluf (1984). Indeed, as the bank is less likely to have an informational advantage over investors about its distant future balance sheet, the risk of adverse selection for the investor in a $\mathrm{CAB}$ is reduced. This advantage plays an important role in the analysis of Bolton et al. (2011), as it ensures that there could be gains from trade ex-ante in the form of a contingent capital issue even though ex post the adverse selection problem is so severe that no new equity issue is feasible in the crisis state. This dynamic adverse selection effect underscores another insurance advantage of equity capital commitments through contingent capital issues. In our quantitative analysis in section III, however, we do not take account of this benefit.

A third advantage of contingent capital, which is outside the scope of the analysis in this paper, is that it helps overcome a major drawback of bank equity capital regulation, namely its pro-cyclical amplification effects. As the costs of building or maintaining a capital buffer fall in boom times and rise in recessions, 
bank lending may amplify rather than dampen boom-and-bust cycles (see e.g. Repullo and Suarez, 2009). In particular, in recessions when it is extremely costly to raise outside equity banks mostly scramble to meet their capital requirements by cutting lending, selling assets, and deleveraging. In the process they amplify the recession by contributing to lowering 'fire-sale' prices of assets. The most compelling evidence to date of these counter-cyclical effects of capital requirements on bank lending is by Jimenez, Ongena, Peydro, and Saurina (2011). They exploit a 'natural experiment' in Spain around the introduction of a new counter-cyclical capital buffer prudential regulation as well as a detailed panel dataset of all bank loans to firms, to determine how changes in regulatory capital constraints affect bank lending. As they point out, this policy experiment allows for exceptionally accurate identification. They find that when capital constraints become tighter banks uniformly respond by cutting back lending; they never respond by relaxing the constraint through a new equity issue. Moreover, the countercyclical capital constraints unambiguously contribute to dampening credit supply cycles.

One way of implementing countercyclical capital constraints is through contingent capital issues, and more specifically through CABs. Indeed, by providing a capital line commitment, a CAB gives the bank the option to issue new capital at favorable terms in a recession and thus to relax its capital constraint. Effectively, a CAB is a form of countercyclical capital constraint but with the added flexibility that the issuer can decide when it is appropriate to relax the constraint, thus reducing the risk of regulatory error and the pressure on regulators to decide when it is appropriate to relax the capital constraint. Moreover, under a $\mathrm{CAB}$ relaxing the capital constraint takes the form of a recapitalization, which further strengthens the bank's balance sheet in a downturn, while under the dynamic provisioning policy in Spain, the relaxation of the capital constraint takes the form of allowing banks to eat into their capital buffer in downturns.

Admati et al. (2011) strongly support a substantial increase in equity-capital requirements and argue that "Approaches based on equity dominate alternatives, including contingent capital". However, the declared superiority of equity capital over contingent capital does not follow from their basic logic. Indeed, they explicitly point to the fact that in terms of outcomes in a crisis state the balance sheets of a highly capitalized bank and a lower capitalized bank, but with added contingent capital, can be identical (see 
Figure 5). It is only in the pre-crisis state that the two balance sheets look different. Our argument is that when there are equity issuing costs over and above the risk-adjusted required ROE then the balance sheet of the bank with contingent capital is more efficient. The extent of the efficiency gain, of course, depends on the size of this issuing cost. If this cost is lower the net benefit of contingent capital is smaller, but still remains positive. In the end Admati et al. (2011) simply assert that contingent capital is too complicated and that straight equity capital requirements are simpler and more effective. Their criticism is targeted at some of the design flaws of other contingent capital instruments and does not directly apply to our design of CABs.

\section{III] CONTINGENT CAPITAL AND CAPITAL ACCESS BONDS}

The design of contingent capital we are proposing in this paper, a Capital Access Bond, gives the issuer of the bond the unconstrained right to exercise the option to repay the bond in stock at any given time during the life of the bond. This instrument is straightforward to set up, easy to value, and hence potentially a highly liquid and marketable derivative. It is effectively an option to issue equity at a prespecified price, with the added feature that the writer of the option puts up collateral to guarantee that it is able to fund the purchase of new equity should the buyer of the put option choose to exercise the option. Indeed, by structuring the bond in this way, the issuer effectively gets the seller of the put (the investor) to assign cash upfront as collateral.

More specifically, under a CAB the bank would issue a bond of a given maturity (say, ten years) with a promised redemption at maturity in the form of either a given amount of common shares, or cash. At maturity, if the stock price falls below the strike price-which is simply given by the principal payment divided by the number of shares the issuer must deliver in lieu of the principal payment-the issuer will choose to deliver shares rather than cash, and if the share price is above this strike price, the issuer has a strong incentive to repay in cash. Up to expiration of the bond the bank can at any time choose to exercise the option by paying back the bond in full with shares. Converting the bond into equity before maturity, however, involves an opportunity cost (namely giving up the option not to convert at a later date). Therefore, the issuer will only do so if the stock price falls sufficiently below the strike price. 
Finally, as long as the issuer has not exercised the option to repay in shares it pays a periodic coupon, which represents the sum of the regular coupon on a bond and the insurance premium on the contingent capital commitment. ${ }^{15}$

\section{III.1 Valuing the Capital Access Bond}

The $\mathrm{CAB}$ is a relatively simple instrument: it is like a plain vanilla convertible bond, with the key difference that the option to convert resides with the issuer and not the investor. Given that it is a relatively standard derivative product, it is straightforward to value using standard option pricing tools, as we discuss next. The main difficulty in valuing this instrument relates to the combined options the issuer has, to both call the bond any time before maturity, and to convert the bond into equity. A "back-of-theenvelope" approach to valuing a CAB is to treat it as a combination of a callable bond and a put option, with the payment of the put premium and call premium spread over the life of the product in the form of regular coupons. We illustrate how to price a $\mathrm{CAB}$ using this approach and also using a more rigorous approach based on the classic trinomial tree method in a numerical simulation using reasonably accurate parameter values for the current market environment ${ }^{16}$.

Table 1: Parameter Values for numerical resolution

\begin{tabular}{|c|c|c|}
\hline Principal Payment: & $\$ 100$ & Issuer's Spread $^{17}$ : \\
\hline Initial Stock Price: & $\$ 100$ & $50 \%$ of Initial Stock Price \\
\hline Maturity: & 10 years & Stock Volatility: \\
\hline Conversion Ratio: & Principal/Strike & Bond Volatility: \\
\hline Treasury Yield: & $2.50 \%$ & Dividend yield $^{18}$ : \\
\hline
\end{tabular}

\footnotetext{
${ }^{15}$ Note that the bond cannot be called by the issuer before maturity by paying the principal back in cash. The reason is that this feature would not help in implementing a contingent equity capital issue for the bank and therefore would be an unnecessary complication, since it would increase the risk for the investor and represent a capital loss.

16 In addition, for a more rigorous "state-of-the-art" approach to price the CAB, refer to annex 2.

17 The issuer's spread is based on the CDS spread for the firm (equal to 90 basis points for a $1.50 \%$ default hazard rate).

${ }^{18}$ Continuous dividend rate.
} 


\section{Valuation by replication}

After selling a capital access bond as specified in our numerical example the issuer is effectively long two put options on the bank's own stock (as the conversion ratio is 2 in our numerical example) and long one option to call the bond at par. Using the parameter values above as inputs in the classic formulae for respectively American put and call options, we obtain that the two American put options are worth $\$ 18.30$ and the American call on the bond is worth $\$ 1.05$, which together amounts to a total of $\$ 19.35^{19}$. The issuer must therefore transfer the combined value of these two options to CAB investors to make them whole. The CAB-holders may obtain this value in the form of an additional spread on each coupon. Thus, if we turn the $\$ 19.35$ into 20 equal semi-annual payments, ${ }^{20}$ we obtain an additional annual coupon spread of $2.37 \%^{21}$.

But, given that there is a positive probability of conversion and that the payment of the option premiums is suspended upon conversion, this estimate must be adjusted so that the expected option premium payments received by the investor (taking into account the probability of conversion) are equal to $2.37 \%$ per year, which by our calculations amounts to an annual coupon of $3.08 \%$. The latter estimate is obtained by using the probabilities of conversion at the end of each time period, which we derive from the price conversion frontier at which the issuer must be indifferent between converting or not converting the CAB. However this ballpark figure is likely to overestimate the size of the coupons ${ }^{22}$, we thus turn to a more rigorous dynamic programming approach.

${ }^{19}$ Note that exercising the option to call the bond here means that the issuer redeems at par at a dollar value equal to the strike price.

20 This transformation is simply finding $\mathrm{x}$, such that 20 equal payments of $\mathrm{x}$ uniformly distributed over 10 years have a total present value of $\$ 19.35$ with the appropriate discount rate (10Y Treasury rate + issuer's spread)

${ }^{21}$ We here and in the rest of the paper use the market convention to convert semi-annual coupons into annual payments by simply multiplying by 2 the semi-annual payments.

22 Adding the issuer's spread to the call and put premiums is excessive as the default risk is already partly incorporated in the put premium (which means that we are double-counting the default risks). Put differently, if the firm goes bankrupt or decides to convert, then the bond part of the product disappears. On the other hand, the put premium does not totally reflect the risk of default (as the CDS spread does). Thus, in order for the risk of default to be properly reflected in the coupon, a fraction of the CDS spread must be added to the put premium. Although, it is difficult to precisely define this extra coupon, what is clear is that the $\mathrm{CAB}$ would have a bigger coupon than subordinated debt: from the investor's perspective, subordinated debt offers a better protection (and so the $\mathrm{CAB}$ should offer a better yield to compensate for this) and from the issuer's perspective, the CAB mitigates the costs of bad states of the world (and so the issuer should be willing to pay a premium compared to subordinated debt). 


\section{Valuation using a classic trinomial tree}

We take a standard dynamic programming approach based on a trinomial tree to describe the possible time paths for the stock price for the whole time period of the CAB. Under this tree there is at any date (or node) a possible constant upward increment in stock price, a downward increment, and no change in price with given constant probabilities. ${ }^{23}$ Following each change in price the issuer can decide whether to convert the bond into stock, or whether to continue servicing the bond. As long as the issuer decides to continue servicing the bond it retains the option to convert into equity, but once conversion has been decided the $\mathrm{CAB}$ is forever converted into equity. This trinomial tree approach gives the same result as when solving the differential equation for the $\mathrm{CAB}$ numerically. A similar approach has been used by Glasserman and Wang (2009) to price their CoCo instrument. As one might expect, the only time when the issuer may choose to convert is just before a coupon distribution.

Using the same parameter values as above, this approach yields an annual coupon of $5.76 \%$. The conversion price frontier over the life of the $\mathrm{CAB}$ at which the issuer prefers to convert is plotted in Figure 1 and the conversion probabilities ${ }^{24}$ at each pre coupon date are plotted in Figure 2.

Figure 1: Conversion Frontier for the Issuer

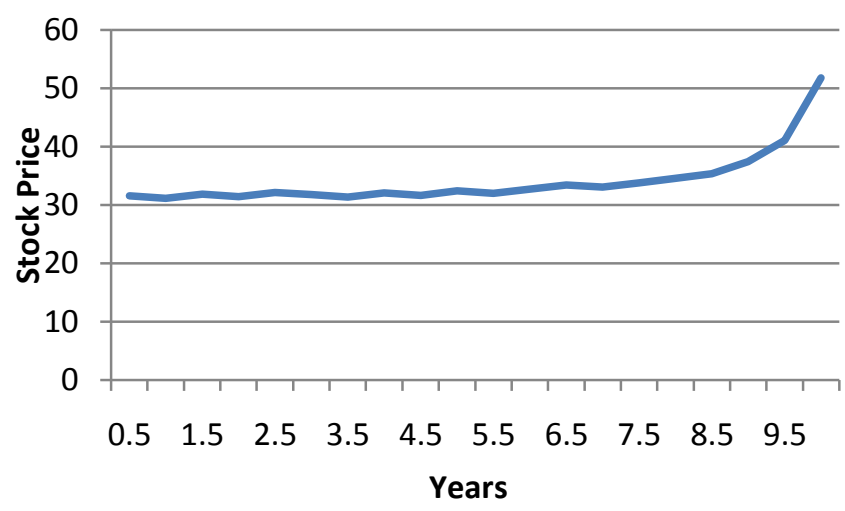

Figure 2: Conversion Probabilities

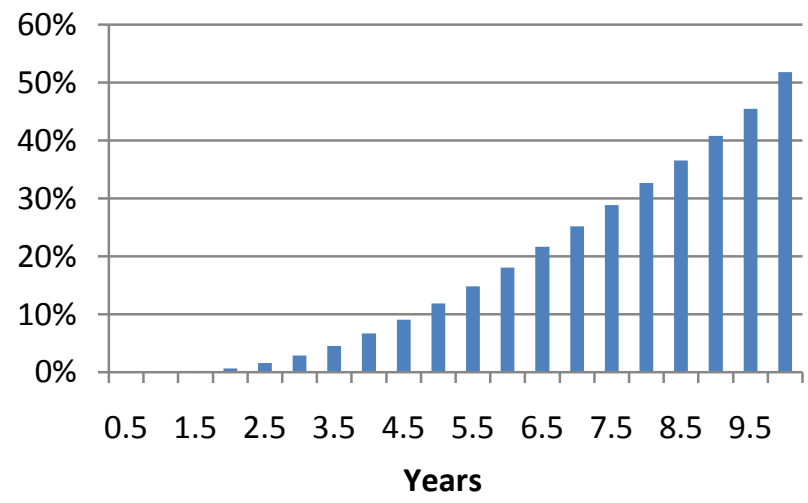

Note that in the early years of the $\mathrm{CAB}$, conversion takes place only at very low prices (around $\$ 30$ ). The reason is that there is a valuable put option built into the CAB: by delaying conversion the issuer

\footnotetext{
${ }^{23}$ In other words, we build a classic recombining trinomial tree with constant volatility and discrete dividend. In our computation we used Matlab with 2000 time steps. More details are provided in Annex 1.

${ }^{24}$ In order to compute these conversion probabilities we have simply computed the probability of each node in the tree of being reached without taking into account the paths which crossed the conversion frontier before reaching the given node. We then just added the probabilities of all the nodes above the conversion frontier to get the probability of non conversion at each time step.
} 
preserves the valuable option not to grant an equity share to the investor, which may turn out to have a high value. Given that the initial stock price is at $\$ 100$, it is very unlikely that the price will drop in a very short time period below $\$ 30$. This is why the probability of conversion is essentially zero in the early years of the $\mathrm{CAB}$, and gradually rising thereafter (see Figure 2). As we highlight in section IV, this feature of the $\mathrm{CAB}$ is the main reason why the risk of investing in a CAB is small. It is also worth emphasizing how much more flexible the $\mathrm{CAB}$ is relative to a contingent capital instrument with an automatic conversion trigger. Indeed, the latter instrument is likely to result in excessive conversion early on.

One way to make this tree more realistic is to add a positive probability to jump to 0 at each time step. This corresponds to a sudden bankruptcy of the bank. ${ }^{25}$ When we do this valuation with a probability of a sudden default (or jump to 0 ) of $0,5 \%$ per year, we get an annual coupon of $6.28 \% .{ }^{26}$

\section{Four Caveats and a Remark}

Although this valuation approach is likely to deliver reasonable estimates in practice, four caveats are nevertheless in order. First and foremost, this valuation model does not take into account any regulatory equity-capital constraints the bank faces. Should the bank approach its equity-capital constraint (e.g. because it faces an unexpected highly profitable investment opportunity) it may want to convert the bond even if this raises the value of the security to investors, simply as an expedient way of relaxing that constraint.

Second, as the bank may be perceived by the market to have superior information about its underlying asset volatility and earnings growth its decision to convert may itself involve signaling effects. For instance, the bank could choose not to convert simply to be able to signal a higher equity value to the market. On the other hand, not converting when the market expects conversion could be counter-

25 Indeed, had the firm seen such a bankruptcy arrive, it would have for sure converted the CABs before. Hence this sudden default probability should only be a fraction of the default probability as given by the CDS spread of the firm.

26 Other valuation models include the state-of-the-art method performed by Ito33, see Annex 2. Another valuation exercise we could have tried is replicating the $\mathrm{CAB}$ by using a down-and-out put option with a knock out barrier at 0 to capture that the $\mathrm{CAB}$ will definitively be worth 0 when the stock price reaches that level. Furthermore a natural way of also computing jumps would have been to perform a Monte Carlo simulation. We could further complicate this model to get even more accurate prices by adding local volatilities depending on the level of the stock price. We could also allow for jumps in stock prices that don't necessarily go to zero but which increase volatility. 
productive as it would signal irrational behavior by the bank, and thus be taken as a "red flag" by investors. In short, there will undoubtedly be signaling effects, which will bias bank's conversion decision. However, it is far from obvious a priori in which direction the bias will be, and how large it will be.

Third, our valuation model assumes that the stock price dynamics are smooth and takes volatility to be constant. In practice, however, the price may jump down in the event of a crisis and/or, volatility may increase sharply at the onset of a crisis. We have excluded these elements from the model mainly for expositional simplicity. It is straightforward to generalize the underlying price dynamics to allow for jumps in stock price and time-varying or stochastic volatility. Conversion is more likely following a jump down in stock price or as the probability of a negative jump increases. In other words, at the onset of a crisis the conversion probability increases, making the bank more resilient. On the other hand, a higher volatility increases the value of the option to delay and thus ought to reduce the probability of conversion.

Fourth, our valuation approach assumes away any public intervention in the bank in the form of a bailout or the like, which would distort the dynamics of the underlying stock price. To the extent that bailouts tend to prop up stock prices they reduce the incentive for the bank to convert. But, conversion reduces the need for a bailout. All in all, how to take account of such interventions is far from obvious a priori.

We conclude this section with an important remark concerning dilution effects of conversion for existing shareholders and the possibility that there may by multiple self-fulfilling equilibria around conversion, as pointed out by Sundaresan and Wang (2010). The CAB is like an American put option, and as such has a well-defined unique conversion frontier. Note also that the economic reason why Sundaresan and Wang (2010) obtain multiple conversion equilibria for contingent capital instruments with an automatic conversion trigger is absent for $\mathrm{CABs}$. The basic economic reason why there may be multiple equilibria in Sundaresan and Wang (2010) is that conversion has the effect of diluting existing shareholders, and therefore to depress the stock price further. This is why expectations of conversion can become selffulfilling: if the market believes that conversion will take place, the price goes down, which triggers conversion; vice-versa, if the market believes there will be no conversion, the price remains above the 
trigger point and the market is again confirmed in its beliefs. Under a CAB, however, there is no positive transfer of value from shareholders to CAB holders at the optimal conversion point (that is, why there is no dilution of existing equity holders upon conversion of the CAB). In other words, the issuer will not choose to call the $\mathrm{CAB}$ if this lowers the value of equity. ${ }^{27}$

\section{IV] A 'COASEAN BARGAIN'}

Having outlined how to structure and value a CAB, we now turn to the analysis of why CABs are a Coasean bargain, making all interested parties better off, issuing banks, investors, and regulators. Issuers are able to maintain an adequate equity capital cushion in bad states of the world at a lower cost. Long-term investors obtain a higher return on investment in $\mathrm{CABs}$ than the coupons earned on regular debt instruments by accepting some downside exposure. And, regulators can achieve greater stability of the banking system, with a lower risk of bailouts.

\section{1 Expected Gains to Issuers}

Issuing contingent capital in the form of a $\mathrm{CAB}$, instead of issuing straight equity, to achieve the same equity capital ratio in a bad state of the world lowers the bank's equity cost of capital as we now illustrate. Using the same parameter values as in our numerical simulation in section III, we compare the expected cost of a contingent capital issue at time zero over the entire ten year period of the model, to a straight equity issue of the same value.

To determine the expected cost of the contingent capital issue, we first compute for every time t the total costs incurred by the issuer if she converts at time t. By converting at time t, the issuer will have paid the coupon on the $\mathrm{CAB}^{28}$ between time 0 and time t, and subsequently (from time t to 10) will pay the return on equity on the new shares issued to the holder of the CAB. Second, by summing the coupon payments and the future costs of the equity newly issued we obtain the total costs to the issuer for a

27 Although Sundaresan and Wang (2010) have found that there could be multiple equilibria for the contingent capital product they consider, it is not clear how this issue affects other types of convertible securities. Indeed this issue, which could arise for classic convertible bonds (which are also dilutive) has not proven to be a concern in the markets.

28 The costs incurred by the issuer up to time $t$ include both the payment of the put premium and the coupon for a regular bond. 
conversion at time t. Finally, by taking expectations for all possible conversion times, we obtain an estimate of the expected cost of a contingent capital issue.

Our estimate of the cost of a straight equity issue, in turn, is given by the cumulative required return on equity (from time 0 to time 10) times the amount of equity issued with the appropriate discounting. As the large body of theoretical and empirical corporate finance literature following Myers and Majluf (1984) has established, the required return on an equity issue is significantly above the return on equity from the $\mathrm{CAPM}^{29}$. Indeed the required return on equity corresponds to the external cost of equity financing for the $\mathrm{bank}^{30}$. Our ballpark numbers for the required return on an equity issue are $10 \%$ on the low side and $20 \%$ on the high side. The annual coupon of $6.28 \%$ we use for the CAB is the one obtained in the trinomial tree model with a jump to 0 . With a $10 \%$ required return on equity the cost of a contingent capital issue is $33 \%$ less than the cost of a straight equity issue for our parameter values (respectively $50 \%$ less taking account of the full tax deductibility of coupon payments), and the reduction in expected cost is even bigger with a $20 \%$ required rate of return, since it amounts to $58 \%$ (respectively $67 \%$ taking account of full tax deductibility).

Table 2: Comparison of the costs of a regular capital issue and a CAB issue

\begin{tabular}{lrrrrr}
$\begin{array}{l}\text { Costs comparison } \\
\text { (present value in \$) }\end{array}$ & $\begin{array}{l}\text { Regular } \\
\text { capital issue }\end{array}$ & CAB issue & $\begin{array}{l}\text { Cost } \\
\text { impact }\end{array}$ & $\begin{array}{l}\text { CAB issue with } \\
\text { tax deductibility }\end{array}$ & $\begin{array}{l}\text { Cost impact with } \\
\text { tax } \\
\text { deductibility }\end{array}$ \\
\hline$R O E=10 \%$ & 88 & 59 & $\mathbf{- 3 3 \%}$ & 44 & $\mathbf{- 5 0 \%}$ \\
$R O E=15 \%$ & 131 & 66 & $\mathbf{- 5 0 \%}$ & 51 & $\mathbf{- 6 1 \%}$ \\
$R O E=20 \%$ & 175 & 73 & $\mathbf{- 5 8 \%}$ & 57 & $\mathbf{- 6 7 \%}$
\end{tabular}

These estimates (which, admittedly, are only based on a partial equilibrium analysis, and do not take into account any possible effects of either form of financing on the costs of the other capital raised by the bank) give an idea of the benefits for an issuer of a $\mathrm{CAB}$ issue. They are conservative given that we take the same ROE for a classic equity issuance and for an equity issuance through conversion of a CAB. The

\footnotetext{
${ }^{29}$ See e.g. Bolton and Freixas (2006) for a theoretical model of bank equity issuance under asymmetric information in the line of Myers and Majluf (1984). As for a empirical studies of the costs of equity issuance including costs due to asymmetric information see e.g. Eckbo, Masulis and Norli (2007).

30 This ROE can be broken down as follows: ROE $=$ risk-free rate $+\beta *$ Risk Premium + Investment Bank Fees + under-pricing at issuance + negative stock price reaction. The investment bank fees for instance vary from $2 \%$ to $6 \%$ of the issued capital. The under-pricing usually accounts for another $10 \%$ of the issued capital. The negative price reaction is estimated to be about $2 \%$ of the total equity value on average (see again Eckbo, Masulis and Norli, 2007).

31 See section VI for further discussion on tax deductibility.
} 
under pricing cost is likely to be lower for CABs since there is probably less asymmetry of information at the time of issue about the future asset values of the bank.

The ex-post gain for the bank of converting CABs once the stock price reaches the conversion frontier, can also be compared to the discount required for a new rights issue at that time. Considering a discount of $10 \%$, Figure 3 shows how favorable the $\mathrm{CAB}$ conversion is relative to a discounted rights issue.

Figure 3: Gain of converting $\mathrm{CAB}$ compared to a discounted rights issue

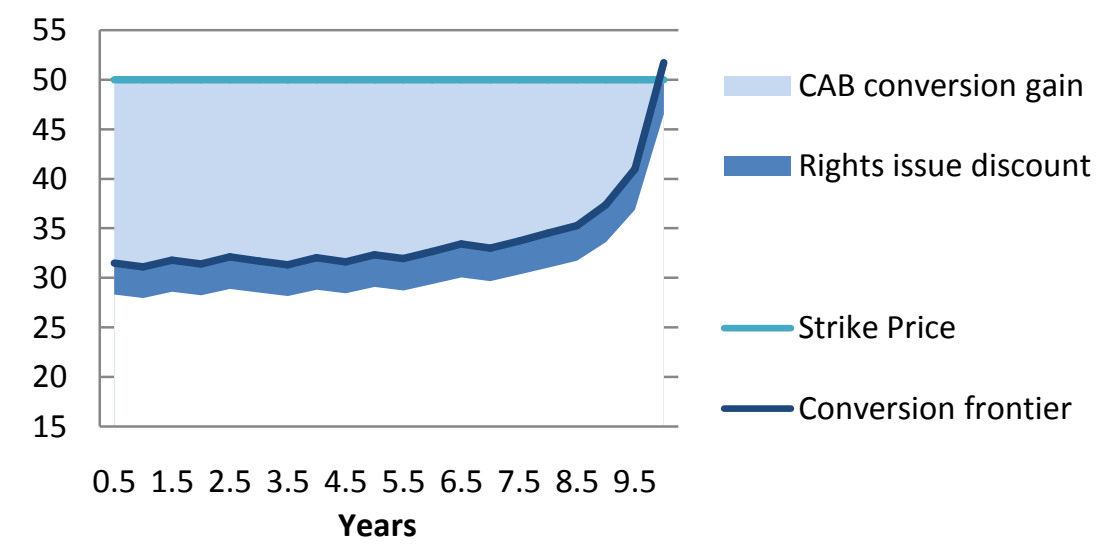

\section{2 Expected gains to Long-term Investors}

The coupon rate $(6.28 \%)$ we have chosen for the $\mathrm{CAB}$ already offers actuarially fair terms to $\mathrm{CAB}$ investors. Note also that in light of the substantial net gains for the issuers of CABs, they can afford to offer even more than actuarially fair terms to attract investors. Judging by the large oversubscription of some contingent capital issues, this is likely what existing issuers (e.g. Credit Suisse) of contingent capital have done. Given that pretty much any investor in a CAB would gain given the terms we specified, we have already established that the $\mathrm{CAB}$ would be a Coasean bargain for issuers and investors. Having said this, it is also interesting to show how much long-term investors - who at the margin face a choice of either holding cash and liquid fixed-income securities or holding CABs_-would gain from investing in CABs. For these long-term investors CABs should be an especially attractive investment. By charging an insurance premium, these investors would be able to monetize their long-term commitment toward a counter-cyclical investment strategy.

To determine investors' expected return, we begin by calculating at each time node $t$ what we define as the effective stock price for the investor, should the issuer decide to convert. The effective stock price is the 
difference between the strike price and the sum of coupons received up to time t. The evolution of the effective stock price is plotted in figure 4.

The reason why we focus on this effective price is that the investor only incurs a loss if the issuer triggers conversion and the stock price is below the effective stock price. Note that from time 0 to time 5 , the conversion frontier is below the effective stock price, meaning that when conversion occurs the $\mathrm{CAB}$ investor actually incurs a loss, while from time 6 to 10 the effective stock price is below the conversion price, so that the $\mathrm{CAB}$ investor only incurs a loss if following conversion the stock price continues to fall below the effective stock price. (see figure 4).

Figure 4: Effective stock price conversion frontier

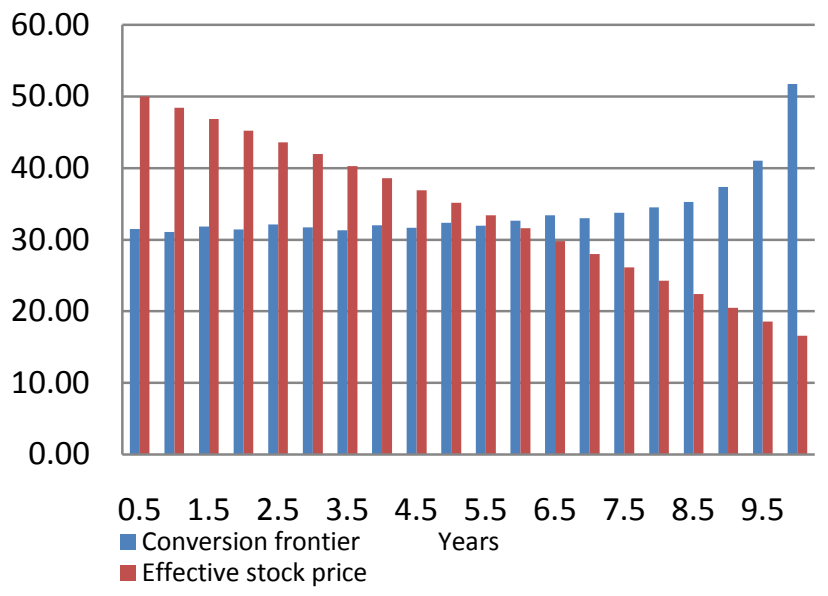

Figure 5: Loss probabilities for the investor

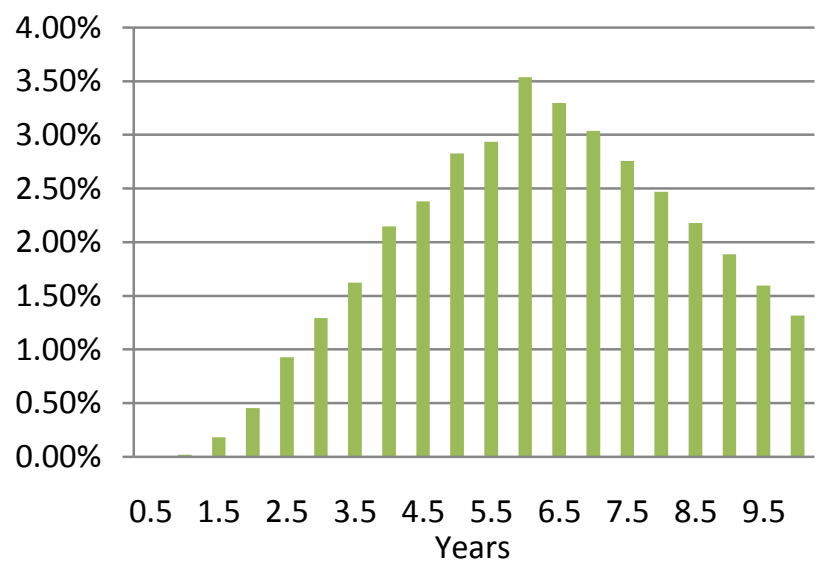

The loss probabilities for a $\mathrm{CAB}$ investor from time 1 to 10 are given in figure 5 . This is an inverted Vshaped curve because the probability of conversion is very low in early years (see Figure 2) and the probability of a loss conditional on conversion is also low in the years close to maturity. By these estimates, an investor gets a 54\% bigger coupon by purchasing the contingent capital security than from a regular bond (in our example $6.28 \%$ compared to $4 \%$ for the regular bond) for a probability of incurring a loss at any time until maturity that is less than $3.5 \%$.

Sovereign wealth funds (SWF) in particular ought to be a natural clientele for CABs, as they currently are overweight in cash and short-term liquid securities. Moreover, SWF due to their long-term horizon, their low redemption risk, and their lack of explicit liabilities, are ideally placed to implement counter-cyclical investment strategies, selling stocks when their price is above trend and buying stocks in downturns. As 
the Norwegian government has notably argued in its Government Pension Fund- Global Annual Report of 2008 (page 19):

"The financial crisis has revealed that many institutions have based long-term investments on short-term funding. When this funding is no longer available, the time horizon for investments quickly becomes very short. Owners and investors have therefore incurred heavy realized losses.

The situation for savings in the Government Pension Fund-Global is different. Its investments are not funded by borrowing, and the institutional framework provides a real assurance of a long-term strategy. Growing risk in the markets will not force us to make changes that result in realized losses for our owners. This long-term approach provides the basis for investment choices that safeguard the fund's long-term returns.

The strategy for the fund means that more equities are purchased when equity prices fall, and fewer when they rise"

Investing in $\mathrm{CABs}$ is a simple way of executing such a counter-cyclical strategy as ultimate equity ownership is contingent on conversion by the issuer in a downturn. A SWF would then not only earn a high return as long as the bond is not converted, but also be automatically set up to buy bank equity when equity prices are low. In particular, the fund would thus be able to monetize this equity investment strategy by charging an insurance premium for its commitment to purchase bank equity in downturns. ${ }^{32}$ Additionally, as the owners of a significant part of global financial assets (which is expected to grow), SWF are particularly exposed to systemic financial crises. If contingent capital mechanisms were widely implemented by financial institutions, this could mitigate systemic risk while rewarding SWF investors. Interestingly the $\mathrm{CAB}$ also replicates the counter-cyclical strategies pursued by the governments sponsoring the SWFs.

\section{3 Benefits for Regulators}

It is not really feasible to accurately quantify the benefits of contingent capital for regulators in a numerical example. Accordingly, we limit ourselves to a qualitative analysis of the benefits of contingent capital for regulators. The first point to recognize is that if banks were to raise a significant fraction of their capital in the form of contingent capital commitments, this would substantially reduce the need for

\footnotetext{
$32 \mathrm{By}$ this analysis it is not entirely surprising that the main investors in contingent capital issued by Credit Suisse were Sovereign Wealth Funds.
} 
regulators to step in by providing emergency lending or by recapitalizing banks. One might argue, following Admati et al. (2011), that the reliance on bail-outs and lender-of-last-resort interventions can also be reduced by simply raising capital requirements. But to the extent that the higher costs of building and maintaining a high capital buffer relative to relying on contingent capital cut into banks' bottom line, banks would either be more fragile or would shrink their operations to avoid the high external costs of equity.

The second point is that there are other advantages of contingent capital commitments besides reducing the need for bailouts in a crisis. We have already mentioned the advantages of contingent capital in terms of helping smooth bank lending over the business cycle. Another useful role of CABs for regulators is that, by observing the premiums banks are paying in the market on their capital access bonds, they would be able to learn both what the market's perception of the underlying risk is for an individual bank and what the capital insurance is worth to the bank. ${ }^{33}$

Given all these advantages of CABs, how could the Basel III regulatory framework accommodate contingent capital? Some of the main changes under Basel III concern the first Pillar, regulatory capital requirements and definitions ${ }^{34}$. The Basel Committee on Banking Supervision (BCBS) has also recently released a consultative document defining another set of rules which only concern SIFI (Systemically Important Financial Institutions). ${ }^{35}$ Perhaps the main change under Basel III is a significant increase in common equity Tier 1 capital requirements ${ }^{36}$. In addition, the new definitions of regulatory capital are more stringent. For instance, Tier 2 regulatory capital must now include a write-down clause, or conversion into common equity, if the bank is deemed to be a gone-concern, that is, if the bank is insolvent or if the responsible authority has declared the bank non-viable without a capital injection or a writedown.

An unresolved question remains whether an additional contingent capital (CoCo) buffer should be added to current capital requirements, at least for SIFIs. This issue has been extensively debated among bank

\footnotetext{
33 Moreover, the observation of the "volatility smile", which is the difference between the implied volatilities of the at-the-money option and the out-of-the-money option, would provide a measure of the probability of a crisis.

34 The documents which form Basel III have been published since July 2010 and can be found on the webpage of the Bank for International Settlements (BIS).

35 As A. Haldane (2011), a member of the Basel Committee has mentioned, Basel III will not make crisis disappear. However it should aim at smoothening them and make sure it is not the taxpayers who pay for the financial system's mistakes.

${ }^{36}$ For details about the changes in minimum regulatory capital requirements, refer to annex 3.
} 
regulators, but so far only the Swiss bank regulatory authorities (FINMA) have chosen to pursue this approach, and have imposed substantial CoCo requirements on Credit Suisse, which has already complied with these regulations, and UBS. The BCBS has argued that contingent capital is an untested instrument that could come in many different forms, and concluded that SIFIs should be required to hold additional loss absorbency capital in the form of common equity Tier 1 capital only, with additional requirements ranging from 1\% to 2.5\% (far below the buffers recommended by Admati et al., 2011 and Greenspan, 2010, and also far below the CoCo requirements of FINMA) ${ }^{37}$. Still, the Basel Committee promises to continue to "review contingent capital, and support the use of contingent capital to meet higher national loss absorbency requirements than the global requirement, as high-trigger contingent capital could help absorb losses on a going concern basis".

How would CABs will be classified under Basel III? Currently a CAB will probably be classified as Tier 2 before conversion due to the "non-perpetual" nature of the instrument. This is already the case for the Lloyds and the Rabobank CoCos. However, since the CAB is designed with a conversion ratio such that conversion will be triggered before the bank becomes a gone-concern (that is, before the Tier 2 holders incur losses) it would be more logical to have CABs ranked as higher quality capital than Tier 2. To comply with the spirit of Tier 1 classification, CABs could thus be modified to be perpetuities, but with an option for the bank to call (and repay in cash) the CAB after a fixed period (say, 10 years).

Note finally that, as far as CABs and CoCos are concerned, bail-ins (or gone-concern contingent capital) are a complementary regulation, a form of last resort resolution once all other measures, including conversion of CoCos or CABs have failed.

37 More precisely, the indicator-based approach comprises five broad categories: size, interconnectedness, lack of substitutability, global cross-jurisdictional activity and complexity. Banks are then split into five buckets with respect to their obtained score which measures their global systemic importance. 


\section{V] PROS AND CONS OF OTHER FORMS OF CONTINGENT CAPITAL}

In this section we briefly compare our $\mathrm{CAB}$ instrument to the other contingent capital instruments and proposals, and discuss their pros and cons.

\section{V.1 Tier 1-based CoCos}

Two examples of contingent capital issues by banks have emanated from the UK. In November 2009, two banks issued different forms of contingent capital. First, the UK Treasury ${ }^{38}$ put in place a contingent capital commitment of $£ 8$ bn with the Royal Bank of Scotland (RBS) under its Bank. Asset Protection Scheme, to be exercised in the event that RBS' Core Tier 1 Capital Ratio falls below 5\%. In return for this commitment RBS is paying the UK Treasury a 4\% annual premium. This is really the simplest possible form of contingent capital: when RBS's Tier 1 capital ratio hits a lower bound, it gets automatically recapitalized with an injection of public money of $f 8 \mathrm{bn}$. Such a simple scheme, with in particular no arrangement to address possible counterparty risk, is only possible given that the counterparty is the UK Government. As such, it is therefore not replicable when private (long-term) investors are the counterparties to the bank. Second, and more germane to our purposes, Lloyds has issued $\AA_{7} 7.5 \mathrm{bn}$ of contingent capital (named Enbanced Convertible Notes) ${ }^{39}$ in exchange for certain existing securities, in particular subordinated debt (Lower Tier 2 capital) with fixed maturities ranging from 10 to 15 years. These securities convert into common stock if Lloyds' core Tier 1 capital ratio falls below 5\%. Since investors in these Enhanced Convertible Notes effectively agreed to exchange a more senior for a more subordinated claim, Lloyds' also agreed to pay a $1.5 \%$ to $2.5 \%$ coupon on top of the one that applies to the existing securities for as long as these notes are not converted into common stock.

These two forms of contingent capital share the feature that the conversion trigger is automatic and is linked to an accounting measure of the bank's Tier 1 capital ratio. This feature is also present in other proposals on contingent capital (see e.g. Duffie, 2009). This particular feature of some existing contingent capital schemes has the drawback that the instrument is more difficult to value. Another

\footnotetext{
${ }^{38}$ RBS website: http:/ files.shareholder.com/downloads/RBS/613513065x0x328836/10a144e0-27ea-4c6c-98f3f276aabfb460/031109.pdf

39 C. L. Culp. Contingent Capital vs. Contingent Reverse Convertibles for Banks and Insurance Companies. Journal of Applied Corporate Finance, Vol 21, Number 4, A Morgan Stanley Publication, Fall 2009.
} 
concern with Lloyds' scheme is that the conversion trigger may have been set too low; so low that it is unlikely to be reached without a prior intervention by bank regulators to force the bank to recapitalize. Thus, investors have so far perceived and priced the Enhanced Convertible Notes as if the conversion probability was negligible.

In recent months contingent capital or CoCos have gained momentum with two other important issues. First, Rabobank, a Dutch cooperative bank was the first to issue a type of CoCo without "forcing" investors to take them. Due to the particular shareholder structure of the bank (it remains a cooperative), the Senior Contingent Notes (SCN) Rabobank issued on the 12 $2^{\text {th }}$ of March 2010 have the specific feature that instead of transforming into shares, they face a $75 \%$ write-down and the remaining $25 \%$ are paid out in cash in the event the bank's Equity Ratio falls below 7\%. However, since Rabobank is considered as one of the most conservative banks in Europe with an Equity Ratio of around 15\%, this is considered to be a very unlikely event. As they put it in their press release ${ }^{40}$ it is designed mainly to hedge against tail risk. Accordingly, the bank has been able to raise $€ 1.25$ bn at a yield of $6.875 \%$ and the issue was more than twice over-subscribed.

Given that Rabobank is considered to be one of the safest banks in the market (triple-A rating) it is not clear whether other less secure banks would face demand for similar products. The latest and probably the most significant CoCo issue is the one by Credit Suisse. As the Financial Times has reported" : "That makes the Credit Suisse deal all the more significant as the next step in the evolution of the market. Rabobank and Lloyds Banking Group have already issued forms of contingent capital but since Rabobank is a mutual, and the Lloyds deal was part of an exchange in stressed circumstances, unlike the planned Credit Suisse CoCo, the deals were not true tests of the market". Credit Suisse has issued $\$ 2$ bn. of Buffer Capital Notes (BCN) on the $17^{\text {th }}$ of February 2011 with a coupon rate of $7.875 \%$ per annum. The bonds convert into equity if the risk-based capital ratio falls below $7 \%$ at any of the calendar quarters and they have a 30 -year maturity.

The $\$ 2$ bn. public issue was more than ten times oversubscribed while most bank analysts were saying that there wouldn't be enough interest from market participants for this type of product. This last point shows that interest for contingent capital does indeed exist in the market. However, it has also been

\footnotetext{
${ }^{40} \mathrm{http}: / /$ www.rabobank.com/content/investor_relations/investor_news/Rabobank_succesfully.jsp

${ }^{41} \mathrm{http}: / /$ www.ft.com/cms/s/0/87ce09e2-3867-11e0-959c-00144feabdc0.html\#axzz1GFvlIXqQ 
pointed out that the missing player in the order book was insurance money. The lack of a credit rating from the Credit Rating Agencies is probably one of the reasons some investors couldn't take part in this first real CoCo issue. Nevertheless, due to the strong interest for these products from market participants, it is probable that the Rating Agencies will find a way to assess CoCos in the near future. ${ }^{42}$

Despite the recent enthusiasm for Tier 1 triggered CoCos, they raise seven recognized concerns. First, their complexity: Tier 1 ratios are variables that are very difficult to compute and monitor under existing risk-weighted-asset (RWA) bank regulations. As Haldane (2011) has stressed, over 200 million calculations could be necessary to determine whether a bank is within its regulatory capital ratio. This is obviously time-consuming and banks can only compute this ratio every quarter. This leads to the second and third concerns: Tier 1 triggered CoCos are subject to model risk. As shown in annex 3, model risk often plays a big role when a bank faces defaults. For instance from the graph of annex 3 we can see that RBS had provisioned four times too little capital to face trading losses due to model risk. This example points to the importance of model risk which is also present when computing RWAs for the Tier 1 ratio. Third, these CoCos lack reactivity: the conversion of such CoCos can only be triggered every 3 months at fixed dates, and, as recent events have amply demonstrated, three months can be a very long time. A fourth concern is the difficulty in pricing these instruments. The trigger is based on an accounting ratio and currently there are no models for the stochastic evolution of such a ratio. In normal times it might seem reasonable to approximate the trigger with a share price threshold since the option is out of the money and hence is not too sensitive to this approximation. However, in times of crisis, the option becomes very sensitive to parameter values and this approximation does not hold anymore, so that the option cannot be priced with any degree of confidence ${ }^{43}$. Fifth, as Haldane (2011) shows in the graph in annex 3, the Tier 1 ratio is not a good predictor of an impending default event. Indeed, the banks that ended up in trouble in 2008 did not have Tier 1 ratios that would have triggered the CoCos. Sixth, this instrument could face a "death-spiral" problem if stock markets, anticipating a conversion, drive down

42 At the same time Credit Suisse arrived at an agreement with strategic investors, Qatar Holding LLC and The Olayan Group, to exchange Tier 1 capital notes issued in 2008 against $\$ 6$ bn of newly issued BCNs. According to the CEO of Credit Suisse Group this amount will allow them to satisfy $50 \%$ of their high trigger requirements imposed by the Swiss Regulator.

43 A possible approach to pricing this product could be to formulate it as a binary option that would have a premium equivalent to the necessary discount to sell shares. Nevertheless, the strike of that option would be unknown and only estimated. Note that mispricing is likely to be less of an issue at the time of issuance since the probability of conversion at that time is low, whereas close to conversion, uncertainty around the product valuation would be maximal. 
the stock price. ${ }^{44}$ Seventh, the bank may choose to engage in costly fire-sales of assets to avoid conversion, which may be perceived to be too dilutive. In contrast, the $\mathrm{CAB}$ addresses all of these problems by simply giving the right of conversion to the issuer. The contingent capital instrument is simple, hence easy to price, liquid during crisis times, reactive and flexible and hence serves best its purpose to prevent a bank from defaulting.

\section{2 Other recent contingent capital proposals}

Contingent capital for banks has been actively debated by regulators, policy makers and academics in the aftermath of the crisis. ${ }^{45}$ One simple early proposal similar to Lloyds' Enhanced Convertible Notes, was to have banks issue subordinated debt that is entirely and automatically converted into common equity if the ratio of tangible common equity to tangible assets falls below a pre-specified threshold (see Duffie, $2009)^{46}$. As Duffie argues, the focus on tangible assets would have the advantage of reducing accounting uncertainty on how capital is measured. He also suggests introducing a regulation requiring banks to undertake an automatic rights offering when they approach the point where their holdings of cash and other liquid assets are dangerously low. Although this scheme would ensure that banks are not overlevered in a crisis there are some potential concerns with the implementation of this form of contingent capital. One problem with the automatic rights offering is that banks would be left exposed to counterparty risk. Also, even if accounting uncertainty is reduced by focusing on tangible assets and common equity it is not entirely eliminated. Moreover, these ratios are not continuously updated, and in particular, they would not respond in time to a rapidly unfolding crisis ${ }^{47}$.

This is why Flannery (2009) has proposed issuing contingent capital securities for which the automatic conversion would be based on the stock price and take place if the issuer's common equity market value falls below $4 \%$ of total assets. Flannery names these securities Contingent Capital Certificates and argues that conversion would be more sensitive to (rapidly unfolding) future adverse shocks and would be subject to

\footnotetext{
${ }^{44}$ Note that Credit Suisse (2011) suggests a cap on the potential shares issued to avoid a death spiral.

45 The Basel Committee on Banking Supervision (2010) has studied various approaches of contingent capital and contingent capital has also been advocated by the Squam Lake Working Group (2010).

46 D. Duffie. A Contractual Approach to Restructuring Financial Institutions. 2009.

47 To address this problem Glasserman and Nouri (2010) propose modifying Duffie's approach by only allowing for a partial and on-going conversion process as the bank's capital-ratio deteriorates.
} 
less accounting manipulation. Unfortunately, however, using the stock price as an automatic trigger could give rise to other problems, as Sundaresan and Wang (2010) have shown. In particular, valuing the Contingent Capital Certificates could be problematic. To address some of these concerns they suggest amending the Contingent Capital Certificates by specifying a coupon indexed so that the Certificates always sell at par. This, however, would substantially increase the complexity of the design of the contingent capital instrument and would not reward the risk taken by investors.

Another variant of Flannery's Contingent Capital Certificates proposed by Mc Donald (2009) is to have two price triggers for conversion: one is the bank's own stock price and the other is a financial stock index. As Mc Donald explains, the added benefit of the second trigger is that conversion would only take place if the entire banking sector is in trouble and not if only one individual bank is in trouble. This has the merit of addressing moral hazard concerns, but, as we have argued, it also comes at the cost of substantially increasing the difficulty of pricing and hedging these contingent capital instruments. Moreover, there remains the potential difficulty in pricing highlighted by Sundaresan and Wang (2010).

Yet another alternative of Flannery's Contingent Capital Certificates proposed by Pennacchi, Vermaelen and Wolff (2010) would specify a (substantially) lower conversion price from the automatic trigger price and also give equity holders an option to repurchase the converted equity from the contingent capital holders, to reduce the risk of equity dilution post conversion. Under this formulation, however, old shareholders need to find fresh capital to fund their buyback of newly issued shares at a moment of financial distress. This would probably come at some cost which could be of the same order as the cost for a classic recapitalization.

Other proposals for bank contingent capital focus less on security design and on implementation of contingent capital via marketable securities. Thus, Acharya, Mehran and Thakor (2010) recommend that banks build up a special capital account through deferred dividend payouts. This capital would be invested in safe assets and would serve as a buffer in case of financial distress. Alternatively, Hart and Zingales (2009) propose that banks be required to raise equity when their CDS spreads rise above a given threshold. Also, under their scheme the prudential bank regulator would intervene if the CDS price does not move back to normal levels within a predetermined period following the equity capital injection. 


\section{VI] REFINEMENTS AND OTHER ISSUES}

There may be concerns with contingent capital about issuer incentives (moral hazrd), stock-price manipulation, and possibly "death spiral" risks. We briefly discuss in this section how the CAB can be tweaked to reduce or even eliminate these potential problems. We also briefly touch on some inevitable implementation complexities relating to the tax, accounting, and regulatory treatments of contingent capital.

\section{1 Moral Hazard}

How is moral hazard affected by the issuance of CABs? The answer depends on whose and what form of moral hazard one has in mind. First, concerning moral hazard in lending, an investor in CABs as opposed to bonds with an explicit or implicit too-big-to-fail (TBTF) guarantee is more likely to engage in due diligence, monitoring and prudent investing in a bank. Second, concerning moral hazard of the issuer, one worry may be that CABs effectively 'soften' a hard budget constraint imposed on the bank in the form of debt financing. This concern, of course, is not warranted if the debt is guaranteed by the bank's TBTF standing. In this case, if anything the CAB will 'harden' rather than 'soften' the bank's budget constraint. But, for other banks the $\mathrm{CAB}$ might weaken somewhat the banker's budget constraint. Any form of insurance (which is what CABs offer) may potentially come at the expense of incentives to maximize earnings. That is not to say, however, that any form of insurance is inefficient. There is a tradeoff between risk-sharing and incentives. Third, some of the negative incentive effects can be mitigated through more high powered incentive schemes. For example, Barclay's has suggested that it might use CoCos instead of cash bonuses to reward its traders and executives ${ }^{48}$. Fourth, in a dynamic setting the conversion of a CAB into equity is far from a pure incentive gift to bank shareholders. Indeed, post conversion the 'upside' of higher earnings for initial shareholders is lower, which creates incentives

48 See "At Barclays, a Pay System That May Please" by Rob Cox, December 5, 2010 New York Times. 
to avoid conversion. Note that this conversion avoidance incentive also has the effect of mitigating excess risk-taking incentives of banks. Moreover, CAB holders are also likely to impose market discipline, as they fear conversion, since they would have to purchase shares at a strike price which may stand significantly above market value. Fifth, contingent capital directly affects managers' discipline. Managers may indeed lose control of the bank after conversion, since control may shift from existing shareholders to the contingent capital holders and a change in management may occur. ${ }^{49}$

\section{VI.2 Price Manipulation}

A point that has been the source of a lot of criticism and confusion with CoCos is price manipulation. This is not so much a concern with CABs, as conversion is an optimal decision for the issuer, which therefore does not give rise to equity dilution and the potential of multiple equilibria in conversion. As Sundaresan and Wang (2010) have shown, this problem is however present with other forms of contingent capital with fixed stock price triggers. Another way of seeing why this is not an issue with CABs is to observe that since conversion is an optimal decision to maximize the long-term value of bank equity, any short-term deviation of the stock price due to a liquidity shock, a freak "flash crash", or possibly strategic shorting of the stock by bondholders hoping to force a conversion of the CAB will have little impact on $\mathrm{CAB}$ conversion. Therefore, share price manipulation is much less of a risk when the bank issues CABs.

\section{VI.3 Strike Price Ladders}

One concern raised by Von Furstenberg (2011) is that a CAB with a single strike price may be too rigid an instrument to deal with all the contingencies that could arise in a crisis. This is a well taken point, which can be addressed by having the bank issue multiple CABs with multiple strike prices, in effect offering a strike price latter through which issuers can convert as a crisis deepens. ${ }^{50}$

\footnotetext{
49 See Himmelberg et al. (2011).

50 Similarly to what is sometimes done for classic convertible bonds, some banks already issued different tranches of contingent capital with different trigger levels. For example, Rabobank issued $€ 1.25$ bn of Senior Contingent Notes and $\$ 2$ bn of Tier 1 perpetual capital securities with respective triggers of $7 \%$ and $8 \%$ for the equity capital ratio.
} 


\section{4 Credit Rating Implications}

The rating of CABs with an embedded put option is very likely to have an impact on their price, and in all expectation the rating agencies will err on the side of caution in rating these new products. Worse still, Moody's is likely not going to rate securities where conversion is either at the bank's option or tied to the activation of pre-specified triggers that are unrelated to the financial health of the bank. Indeed, a recent report ${ }^{51}$ by Moody's indicates that "the unpredictable and non-credit linked elements surrounding these triggering events make the instruments unsuitable for a fixed income rating."

As for Standard \& Poor's, it considers that conversion features based on regulatory capital increase the risk of loss to investors ${ }^{52}$. Therefore, CABs with such triggers would be rated by S\&P "at least one notch below a similar issue without the contingent capital trigger". Also, S\&P recommends the frequent tracking of the triggering capital ratio to protect more senior bond holders: "If the issuer moves closer to the trigger point, we could lower the rating further to reflect the increased risk relative to other junior instruments in the issuer's capital structure.”

However, Fitch has moved forward and has rated the Credit Suisse CoCo BBB+. The other two agencies will now probably follow especially since the Credit Suisse issuance has faced so much demand. No rating agency wants to miss out on such a huge potential market. Note finally that as much as there may be a greater risk of loss for the holders of $\mathrm{CABs}$, other (more senior) debt instruments receive greater protection with the conversion feature, as it provides an additional equity cushion to absorb potential losses. Therefore, these other debt instruments should logically receive a more favorable treatment by the rating agencies.

\section{5 Taxation of CABs}

A full deductibility of coupon payments from corporate taxation would provide a powerful incentive to issue CABs. The most likely and already implemented tax treatment is for the CAB to be considered as debt. Indeed both Rabobank's Notes, Lloyd's and Credit Suisse's CoCo's are tax deductible. And, as Pennacchi, Vermaelen and Wolff (2010) argue: "it would be ironic if the government would discriminate

\footnotetext{
${ }^{51}$ Moody's. Rating Considerations for Bank Contingent Capital Securities. February 2010.

52 Standard \& Poor's Ratings Services. Criteria Regarding Contingent Capital Securities. October 2009.
} 
against debt" a product "that reduces the likelihood of a financial crisis" and doesn't have the unlimited upside of equity.

A client briefing by the law firm Clifford Chance ${ }^{53}$ suggests a second possibility: that the portion of the coupon payment attributable to the payment of the option premium would probably not to be treated as interest and thus, would not be tax-deductible. Also, the issuer may be taxed on an income basis in order to account for the fair value movements on the embedded derivative (recorded on the balance sheet as a derivative asset), as is the case in the UK. However, the complexity of this solution makes this treatment unlikely. The last possibility could be that governments treat CABs more like equity than debt for tax purposes. This scenario is the likeliest in the US according to Barclay's Capital ${ }^{54}$. However as they argue, the rules are not that clear and some exceptions already exist for insurance companies.

\section{6 Accounting treatment}

According to a report by Ernst \& Young ${ }^{55}$, the accounting treatment of contingently convertible debt is as follows:

1) Under US GAAP, "Potentially issuable shares are included in diluted Earnings Per Share (EPS) using the "if-converted" method if one or more contingencies relate to the entity's share price";

2) Under international standards (IFRS), "Potentially issuable shares are considered "contingently issuable" and are included in diluted EPS using the if-converted method only if the contingencies are satisfied at the end of the reporting period."

Also, the Enbanced Capital Notes issued by Lloyds Banking Group, have received the following accounting treatment: the bond part of the security has been classified as a subordinated liability and is reported at fair value, while the embedded put option is recorded as a derivative asset, carried at fair value ${ }^{56}$. Thus, in particular, changes in the fair value of the derivatives are recognized as unrealized gains or losses each reporting period: if the stock price decreases, then there is a positive impact on the put valuation.

\footnotetext{
53 Clifford Chance. Client Briefing. November 2009.

${ }^{54}$ U.S. Banks, Limited CoCo Issuance Expected, March 2011, Credit Research

${ }^{55}$ Ernst \& Young. US GAAP vs. IFRS, The basics. January 2009.

${ }^{56}$ Lloyds Banking Group. Annual Report and Accounts. 2009.
} 


\section{7 Takeovers and CABs}

If a bank that has issued CABs is the target of a takeover bid, the bidder will have to make an exchange tender offer on the securities, similar to what is usually done for convertible bonds. However, one complication which might arise is if the bidder acquires all the CABs and gives an incentive to management to trigger conversion, even though the option is far out of the money for the bank. This would allow the bidder to buy shares at a big discount. A protection clause must therefore to be included to avoid this. Furthermore as some regulators in Europe fear, contingent convertibles could enable some actors to suddenly hold large shares of their banks without prior approval. This problem could also easily be solved by taking the conservative standpoint of including CoCos in all statutory shareholding thresholds crossings. It goes without saying that when the bank is facing a situation where it needs an additional capital buffer to continue business, the regulator may well prefer an undesired new shareholder to a bank failure which puts the economy at risk.

\section{8 Death Spirals and Contagion}

What is likely to happen with the stock price when conversion occurs? One of the concerns is that new shareholders will be selling their shares, putting further pressure on stock price and possibly triggering further conversion. In short, that the bank will be sucked into a 'death spiral'. This concern is particularly relevant for CoCos with automatic price triggers. However, for CABs the likely effect of conversion is to lead to an increase in price, as conversion means that new equity has been purchased at above market value, thus leading to a net increase in market capitalization. Note also that if the risk of a sell-out still remains a concern, banks could counter this risk by introducing special rewards to 'loyal' shareholders (see e.g. Bolton, Samama, 2010 and Coffee 2010).

Another concern besides 'death spirals' is contagion. If CABs are held by other financial institutions conversion may affect their bottom line and raise concerns about systemic risk. To avoid this contagion fear the simplest response is to make sure that CABs are not held by other banks. Financial Institutions 
can be discouraged to invest in other banks' CABs simply by applying an onerous risk weighting to these assets. As we have argued above, SWFs would be ideal investors in CABs. Interestingly, the Credit Suisse CoCo issue has revealed that these investors are indeed interested in these high premium products.

\section{9 Catalyzing CABs}

To induce banks to issue CABs regulators have powerful tools at their disposal. First, they can make CABs entirely tax deductible as it is the case with debt. Second, the regulator could add these forms of liabilities to the new regulatory capital framework as is the case in Switzerland. Third, as Haldane (2011) argues, banks could be enticed to pay bonuses to employees ${ }^{57}$ in the form of contingent capital. This would create a first market for such products and help catalyze the launch. Fourth, as stressed by Himmelberg et al. (2011), the inclusion of contingent capital securities in credit indices will also be an important factor, perhaps even more important than obtaining a rating. Furthermore, some regulators, especially in Europe are in the process of setting up support funds for banks. It would make sense for these funds to invest in such products. Finally, as stressed in Ervin (2011), the pull for contingent capital is likely to come from investors rather than regulators Indeed, in the new perspective of Basel III, efforts are made to avoid bail-outs by governments and impose private bail-ins. Increasing investor demand for bail-in protection is thus likely to pull the demand for contingent capital, as it provides an additional layer of protection and decreases the likelihood of a bail-in of more senior investors.

\section{VI.10 Communication around CAB Issues}

Finally, one last word of caution: issuers and the associated syndicates should be careful to describe appropriately the risks associated with this type of product. In particular, in case there is any doubt, it should be clearly mentioned that the risk is different from the risk of a classic or a subordinated bond. Furthermore, it is essential that banks enhance and standardize disclosure. As stressed in Himmelberg et al. (2011), whatever the structure of contingent capital, banks need more horizontally comparable,

57 The CEO and all members of the board who decide whether to trigger the CAB should for evident conflicts of interest, be excluded from the employees receiving CABs. 
comprehensive and consolidated reporting, along with more robust marks to allow markets to have enough information to actually impose discipline on financial firms.

\section{VII] CONCLUSION}

We believe the economic case for a contingent capital solution to foster greater stability of the banking system is compelling. At the very least, contingent capital is a superior investment in banks for long-term investors than equity investments at the onset of a recession, "when equity prices fall", as it lets longterm investors charge an insurance premium for the "capital-line commitment" they provide, and also protects long-term investors against the risk of investing in "lemons" in a crisis.

The performance of sovereign wealth fund investments in bank equity in the summer of 2007 has been disappointing to say the least ${ }^{58}$. It would be highly regrettable if the lesson sovereign wealth funds take from this experience is to simply stay out of bank equity investments. The way forward instead, ought to be to pursue a similar long-term investment strategy as Berkshire Hathaway and to sell long-term puts on bank equity. This would let both long-term investors reap a compensating return on their investments, and provide banks with a lower cost of meeting an adequate equity capital target in a downturn.

If the case for contingent capital is so compelling, this naturally raises the question why banks have not made greater use of this financing instrument before the crisis. Why did we have to wait for a nearly cataclysmic crisis to occur to start thinking about contingent capital? There are a number of answers one can offer to this question. As with any successful financial innovation, a first reason may be simply a lack of imagination before the innovation has been introduced and tested. A second reason may be linked to bank regulatory barriers and regulatory conservatism: if the regulatory classification of contingent capital was too conservative it could have made sense for issuers to concentrate instead on other securities, which received a more favorable treatment under Basel II. Alternatively, if banks were able to circumvent regulatory equity capital requirements through off balance-sheet, "shadow banking" operations, they would not have perceived the need to secure more equity capital through contingent capital commitments. This may be the reason why, unlike monoline insurers, we have not seen banks use this

58 The list of the investments is provided in annex 4. 
form of financing before the crisis. Another related reason may be that banks never perceived a need for a "capital-line commitment", as they could count on contingent public liquidity provision through quantitative easing, and possibly even on "bailouts". Indeed as we have seen during the crisis, a lot of banks were conscious they were "too big to fail" and hence believed that the government had sold them a put option on a capital issuance for free. It therefore didn't make any sense to buy this put option or insurance from a private investor when the state provided the same for free with no counterparty risk. However as we have seen recently with Ireland in particular, some countries won't have the financial power to rescue every bank, hence reintroducing counterparty risk. Furthermore, public opinion is pushing for less support of the banking system going forward. This will definitely encourage more banks to consider contingent capital issuances in the near future. In addition, banks are aware that the more precarious state of public finances makes another bailout infeasible in the short and medium run, thus increasing the benefits of securing a "capital line of credit" from long-term investors. 


\section{REFERENCES}

J. Ackermann, (2010), “The new architecture of financial regulation: Will it prevent another crisis?”, LSE Financial Markets Group Paper Series, Special paper 194

V. Acharya, H. Mehran and A. Thakor. (2010), "Caught between Scylla and Charybdis? Regulating Bank Leverage when there is Rent Seeking and Risk Shifting", Federal Reserve Bank of New York Staff Report No. 469.

http://ssrn.com/abstract $=1673485$

R. Admati, P. Demarzo, M._Hellwig and P. Pfleiderer, (2011), "Fallacies, Irrelevant Facts, and Myths in the Discussion of Capital Regulation: Why Bank Equity is Not Expensive”, Research Papers 2065, Stanford University, Graduate School of Business, March

B. Albul, D. Jaffee and A. Tchistyi, (2010), "Contingent convertible bonds and capital structure decisions", working paper, Univeristy of California Berkeley.

F. Allen and R.Michaely, (2003), "Payout Policy", in the Handbook of the Economics of Finance, edited by George Constantinides, Milton Harris and René Stulz, North-Holland.

Barclays Capital Credit Research, (Mar 2011), U.S. BANKS, “Limited CoCo Issuance Expected”

Basel Committee on Banking Supervision, "Global systemically important banks: Assessment methodology and the additional loss absorbency requirement”, Consultative Document, July 2011 http://www.bis.org/publ/bcbs201.htm

L. Bebchuk, (1988) "A New Approach to Corporate Reorganizations," Harvard Law Review, Vol. 101, No. 4: $775-804$

Berkshire Hathaway Inc. Annual Report. 2007, 2008, 2009, 2010.

B. Bernanke and C. Lown, (1991), "The Credit Crunch.” Brookings Papers on Economic Activity, no. 2: 204-39

P. Bolton and F. Samama, (2010), "L-Shares: Rewarding Long-term Investors", Mimeo, Committee on Global Thought, Columbia University:

http://cgt.columbia.edu/conferences/sovereign_wealth_funds_a_new_form_of_capitalism/papers/1shares_rewarding_long-term_investors/

P. Bolton and F. Samama, (2011), "Capital Access Bonds: Securities Implementing Counter-Cyclical Investment Strategies", in Sovereign Wealth Funds and Long-Term Investing, co-edited by P. Bolton, F. Samama and J. Stiglitz, Columbia University Press

P. Bolton, T. Santos and J. Scheinkman. (2011), "Outside and Inside Liquidity", Quarterly Journal of Economics, 126(1): 259-321.

C. Calomiris and R. Herring, (2011), "Why and How to Design a Contingent Convertible Debt Requirement"

http://ssrn.com/abstract $=1815406$ 
Clifford Chance. Client Briefing. November 2009.

J. Coffee, (2010), "Bail-Ins Versus Bail-Outs: Using Contingent Capital to Mitigate Systemic Risk", Columbia Law and Economics Working Paper No. 380.

C. L. Culp, (2009), "Contingent Capital vs. Contingent Reverse Convertibles for Banks and Insurance Companies", Journal of Applied Corporate Finance, Vol 21, Number 4

Deloitte, “IFRSs and US GAAP: A Pocket Comparison”, An IAS Plus Guide. July 2008.

E. Dimson, A Ilmanen, E Liljeblom and Ø Stephansen (2010), "Investment Strategy and the Government Pension Fund Global"

http://www.regjeringen.no/Upload/FIN/Statens\%20pensjonsfond/SR_Final_GPFG_25Nov.pdf

A. Drew, R. Frogley, T. Hayward and R. Sethi, (2008), "Strategic Tilting around the SAA Benchmark", nzsuperfund.co.nz.

D. Duffie, (2009), "A Contractual Approach to Restructuring Financial Institutions", Chapter 6 in Ending Government Bailouts as We Know Them

Edited by Kenneth E. Scott, George P. Shultz, and John B. Taylor, Hoover Institute Press

B. E. Eckbo, R. W. Masulis and O. Norli, (2007), "Security Offerings," In B. E. Eckbo (ed.) Handbook of Corporate Finance: Empirical Corporate Finance, Vol. 1

Ernst \& Young, (2009), "US GAAP vs. IFRS, The basics"

W. Ervin, (2011), “A new pull for CoCos“, Credit Suisse, Risk August 2011

M. J. Flannery, (2002), "No Pain, No Gain? Effecting Market Discipline Via 'Reverse Convertible Debentures". Available at SSRN: http://ssrn.com/abstract=352762 or doi:10.2139/ssrn.352762

M. J. Flannery, (2009), "Stabilizing Large Financial Institutions with Contingent Capital Certificates", http:// ssrn.com/abstract $=1485689$

P. Glasserman and B. Nouri, (2010), "Contingent Capital with a Capital-Ratio Trigger http://ssrn.com/abstract $=1669686$

P. Glasserman and Z.Wang, (2009), "Valuing the Treasury's Capital Assistance Program”, Federal Reserve Bank of New York, Staff Report No. 413.

J. N. Gordon(2010), "Executive Compensation and Corporate Governance in Financial Firms: The Case for Convertible Equity-Based Pay", Columbia Law and Economics Working Paper No. 373. http:// ssrn.com/abstract $=1633906$

C. Himmelberg, A. Hindlian, S. Lawson and L. Pitt, (2011), "Contingent Capital: Possibilities, problems and opportunities, Goldman Sachs Global Market Institute”, March

A. Greenspan, (2010), “The Crisis”, Brookings Papers on Economic Activity, Spring 2010

A. Haldane, (2011), “Capital Discipline”, Speech, Bank of England 
S. Hanson, A. Kashyap and J. Stein (2010), "A macroprudential approach to financial regulation", Journal of Economic Perspective, 25:1, Winter 2010, pp. 3-28.

O. Hart and L. Zingales, (2009), "A New Capital Regulation For Large Financial Institutions", Fondazione ENI Enrico Mattei, Nota di Lavoro 124.2009.

J. Hull, (2010), “Options, Futures, and other Derivatives”, Prentice Hall

IMF. Global Financial Stability Report, "Navigating the Financial Challenges Ahead" World Economic and Financial Surveys, October 2009

M. C. Jensen, (1986), "Agency Costs of Free Cash Flow, Corporate Finance and Takeovers", American Economic Review, Vol. 76, No. 2.

G. Jiménez, S. Ongena, J.-L. Peydró and J. Saurina (2011), "Macroprudential Policy, Countercyclical Bank Capital Buffers and Credit Supply: Evidence from the Spanish Dynamic Provisioning Experiments", Bank of Spain mimeo.

A. K. Kashyap, R. G. Rajan and J. C. Stein, (2008), "Rethinking Capital Regulation", University of Chicago Working Paper

Lloyds Banking Group. Annual Report and Accounts. 2009.

R. L. Mc Donald, (2009), "Contingent Capital with a Dual Price Trigger" http://ssrn.com/abstract $=1553430$

Moody's (2010), "Rating Considerations for Bank Contingent Capital Securities”

S. Nixon, "Lloyd Banking on Contingent Capital for Escape”, Wall Street Journal. November 2009

C. Pazarbasiolu, J. Zhou, V. Le Leslé, M. Moore, (25 Jan 2011), “Contingent Capital : Economic Rationale and Design Features”, IMF Staff Discussion Note SDN/11/01,

http://www.imf.org/external/pubs/ft/sdn/2011/sdn1101.pdf

G. Pennacchi, (2010), "A Structural Model of Contingent Capital”, Federal Reserve Bank of Cleveland Working Paper No. 10-04.

http:// ssrn.com/abstract $=1595080$

G. Pennacchi, T. Vermaelen and C. Wolff, (2010), "How next time to save banks without taxpayers' money: the case for COERCs", INSEAD Working Paper No. 2010/55/FIN.

http://ssrn.com/abstract $=1656994$.

Royal Bank of Scotland

http:/ / files.shareholder.com/downloads/RBS/613513065x0x328836/10a144e0-27ea-4c6c-98f3-

f276aabfb460/031109.pdf

A. Raviv, (2004). "Bank Stability and Market Discipline: Debt-for-Equity Swap versus Subordinated Notes," Finance 0408003, EconWPA 
R. Repullo and J. Suarez, (2010), “The procyclical effects of bank capital regulation”, Tilburg University, Center for Economics Research, Discussion Paper 2010-29S

J. R. Ritter, (1987), “The costs of going public", Journal of Financial Economics, Vol. 19, Issue 2, pp. 269281.

J. R. Ritter, (2003), "Investment Banking and Securities Issuance", ", in the Handbook of the Economics of Finance, edited by George Constantinides, Milton Harris and René Stulz, North-Holland.

Squam Lake Working Group on Financial Regulation, (2010), "An Expedited Resolution Mechanism for Distressed Financial Firms: Regulatory Hybrid Securities"

Standard \& Poor's Ratings Services. Criteria Regarding Contingent Capital Securities. October 2009.

S. Sundaresan and Z. Wang, (2010), "Design of contingent capital with a stock price trigger for mandatory conversion", Federal Reserve Bank of New York, Staff Report No. 448.

M. Szymanowska, J. Ter Horst and H. Veld, (2008), "Reverse Convertible Bonds Analyzed", Journal of Futures Markets, 29 (10): 895-919

http:/ / ssrn.com/abstract $=730543$

G. M. von Furstenberg, (2011), "Concocting marketable CoCos", Hong Kong Institute for Monetary Research, Working Paper No. 22/2011

World Federation of Exchanges

http://www.world-exchanges.org/statistics 


\section{Appendix}

\section{Annex 1 Building the trinomial Tree}

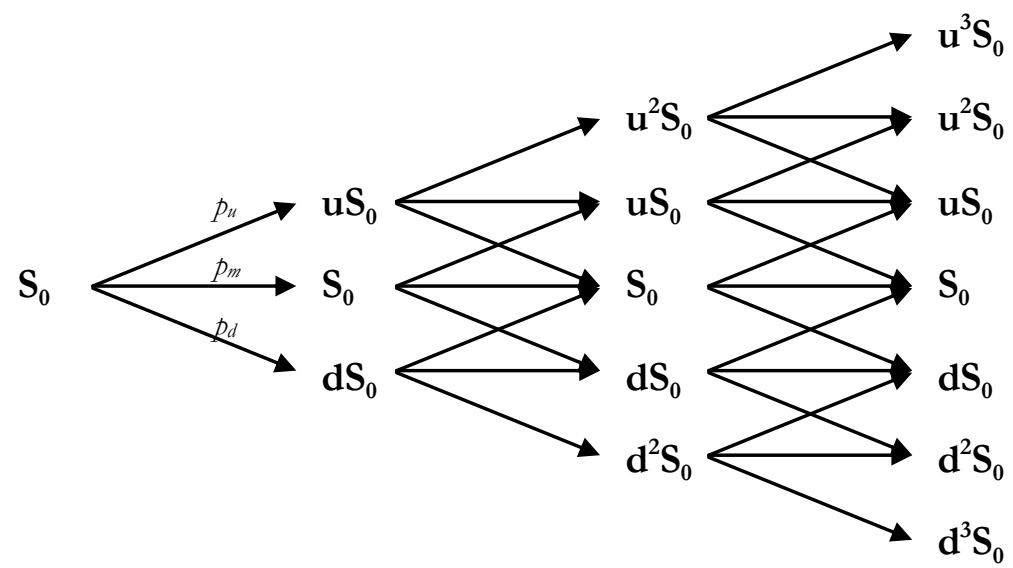

We assume that the stock pays a semi-annual dividend of $2 \%$. At each node, $u$ and $d$ are the respective sizes of the up and down jumps, with probabilities $p_{u}$ and $p_{d}$. With probability $p_{m}$ the stock price $S_{n}$ remains unchanged:

$$
\begin{gathered}
u=e^{\sigma \sqrt{2 \Delta t}} \quad \text { and } \quad d=e^{-\sigma \sqrt{2 \Delta t}} \\
p_{u}=\left(\frac{e^{\frac{r \Delta t}{2}}-e^{\frac{-\sigma \sqrt{\Delta t}}{2}}}{e^{\frac{\sigma \sqrt{\Delta t}}{2}}-e^{\frac{-\sigma \sqrt{\Delta t}}{2}}}\right)^{2} \quad p_{d}=\left(\frac{e^{\frac{\sigma \Delta t}{2}}-e^{\frac{r \sqrt{\Delta t}}{2}}}{e^{\frac{\sigma \sqrt{\Delta t}}{2}}-e^{\frac{-\sigma \sqrt{\Delta t}}{2}}}\right)^{2} \\
\text { and } \quad p_{m}=1-p_{u}-p_{d}
\end{gathered}
$$

This is one of the possible parameterizations for a risk-neutral recombining $\left(u=\frac{1}{d}\right)$ trinomial tree with the following constraints to match the first two moments of the stock price model distribution:

$$
\begin{aligned}
& \mathbb{E}\left[S_{n+1} \mid S_{n}\right]=e^{r \Delta t} S_{n} \\
& \mathbb{V}\left[S_{n+1} \mid S_{n}\right]=\sigma^{2} \Delta t S_{n}{ }^{2}+O\left(\Delta t^{3 / 2}\right)
\end{aligned}
$$

We then add the discrete dividend payment using the Hull approximation (see Hull, 2010). At each node we now compute the price of the $\mathrm{CAB}$ by reverse induction using the following equality:

$\mathrm{CAB}_{\mathrm{n}}=\max \left(\mathrm{e}^{-\mathrm{r \Delta t}} \mathbb{E}\left[\mathrm{CAB}_{\mathrm{n}+1} \mid \mathrm{S}_{\mathrm{n}}\right], \mathrm{B}_{\mathrm{n}}-2 \mathrm{~S}_{\mathrm{n}}+\mathrm{RP}_{\mathrm{n}}\right)=\max \left(\mathrm{X}_{\mathrm{n}}, \mathrm{Y}_{\mathrm{n}}\right)$, where:

$$
X_{n}=e^{-r \Delta t} \mathbb{E}\left[C A B_{n+1} \mid S_{n}\right] \quad \text { and } \quad Y_{n}=B_{n}-2 S_{n}+R P_{n} \text {, }
$$

the terminal value at maturity being: $\quad \mathrm{Y}_{\text {final }}=\mathrm{B}_{\text {final }}-2 \mathrm{~S}_{\text {final }}$, 
and where:

$\mathrm{B}_{\mathrm{n}}$ is the par value of the bond plus accrued coupon. This relies on the assumptions that interest rates are constant $^{59}$ and that the $\mathrm{CABl}$ always converts before the issuer defaults. This last assumption is equivalent to ignoring the instant default risk (we later relax this assumption);

$\mathrm{S}_{\mathrm{n}}$ is the value of the stock price at time $t_{n}$;

$\mathrm{RP}_{\mathrm{n}}$ is the value of remaining principal to be paid via an additional spread on the coupon of the CABs; $\mathrm{r}$ is the risk free rate;

$\Delta \mathrm{t}$ is the time step between two nodes in the trinomial tree;

We compute the value of the $\mathrm{CAB}$ at each node as follows: We first assume that the remaining principal is 0 at each node, and that the bond pays the riskless rate. By backward induction we then compute the price at inception of the CAB. Let $\mathrm{CAB}_{0}$ be this price. We also compute our risk-neutral conversion frontier and conversion probability. The conversion frontier is simply the highest value of $S$ for a given time t where $X_{n} \leq Y_{n}$ (i.e. when the expected value of not converting the $\mathrm{CAB}$ at time $\mathrm{t}$ is less than the value after conversion). Note that the only times when it is more advantageous to convert rather than wait is just before the coupon payments. Hence there are only 20 dates in our case where the issuer is likely to convert. We denote by $\mathrm{C}$ the column vector denoting the conversion frontier with each $\mathrm{C}_{\mathrm{i}}$ corresponding to the date just prior to the coupon payment. Similarly, we use this conversion frontier to compute the conversion probability, which is the probability that a node is attained in our tree without previously crossing the conversion frontier. Let $\mathrm{P}$ be the column vector representing the conversion probabilities at each of the 20 dates prior to the coupon payments.

${ }^{59}$ Note that the model could account for interest rate risk. All that would be required is to design the CAB by promising a floating rather than a fixed coupon. Specifically, the CAB could pay a coupon equal to the sum of three month Libor, the prevailing bank spread over Libor, and the value of the embedded put options. Examples of instruments with this floating coupon feature are the convertible bonds recently issued by the National Bank of Abu Dhabi (in February 2008) and Fortis Bank (in November 2007) which had a coupon based on a floating rate (offered rate of the three-month Arab Emirates Dirham (AED) deposits and 3-month EURIBOR respectively). Note that this product would still have a sensitivity to the issuer's spread and to the put premium coupon. 
Next, we distribute this value in additional equal coupon payments (AECP) on the bond. We can separate the AECP into two parts: the interest payment $\left(\mathrm{IP}_{\mathrm{i}}\right)$ and the principal repayment $\left(\mathrm{PR}_{\mathrm{i}}\right)$. The remaining principal is simply $R P_{n}=\mathrm{CAB}_{0}-\sum_{1}^{\mathrm{n}} \mathrm{PR}_{\mathrm{i}}$, where $\mathrm{n}$ is the number of coupons which have already been paid.

We also have to take into account the probability that the coupon payments are suspended due to the positive probability of conversion. Accordingly, we use the riskless probability of conversion and make sure that the expected present value of the $\mathrm{AECP}$ is equal to $\mathrm{CAB}_{0}$. If we denote by $\mathrm{D}$ the discount vector with $\mathrm{D}_{\mathrm{i}}$ the discount factor at each coupon payment i. Hence we are looking for AECP such that:

$A E C P=\frac{1}{\mathrm{CAB}_{0}}{ }^{T} D \cdot P$

We next plug in the remaining principal in each node of our tree, which will restart the loop, and we get the AECP once the loop has converged.

\section{Annex 2 The analytical valuation performed by Itô33}

A rigorous state-of-the-art approach to valuing the $\mathrm{CAB}$ takes into account both the volatility of the underlying and the issuer's default hazard rate modeled as a Poisson process ${ }^{60}$. If we use the same parameters as in the main text and assume a zero recovery on the $\mathrm{CAB}$ in the event of bankruptcy, the corresponding annual coupons under this more rigorous approach are shown in the table below. Note that the values of the options are affected by both the Brownian volatility (fixed at 35\% in our model) and the default Poisson process which sends the spot price to zero.

\begin{tabular}{|c|c|c|c|}
\hline Default rate & CDS 10Y 40\% recovery (bps) & Implicit Volatility Put 50 10Y & Coupon \\
\hline $1.50 \%$ & 90 & $41.32 \%$ & $6.15 \%$ \\
\hline $6.00 \%$ & 361 & $58.87 \%$ & $10.00 \%$ \\
\hline $9.00 \%$ & 541 & $69.82 \%$ & $12.79 \%$ \\
\hline
\end{tabular}

Using this more rigorous approach we can also determine the conversion price at any point in time at which the issuer should exercise the option. As we have already noted, at maturity this conversion price is simply the

60 We are thankful to the company Ito33 for carrying out this pricing simulation and sharing their results. 
strike price of $\$ 50$. Before the expiration of the options, however, the conversion price will be strictly lower than $\$ 50$, as early conversion involves an opportunity cost in the form of lost future put and call options. Roughly speaking, the conversion price before maturity is given by the price at which the two newly issued shares have the same value as the fair value of the redeemed security. Or, in options parlance, the conversion price is given by the price at which the delta of the product is equal to $100 \%$. In other words, at conversion the change in value of the combined options with a $\$ 1$ change in the underlying stock price is equal to one ${ }^{61}$.
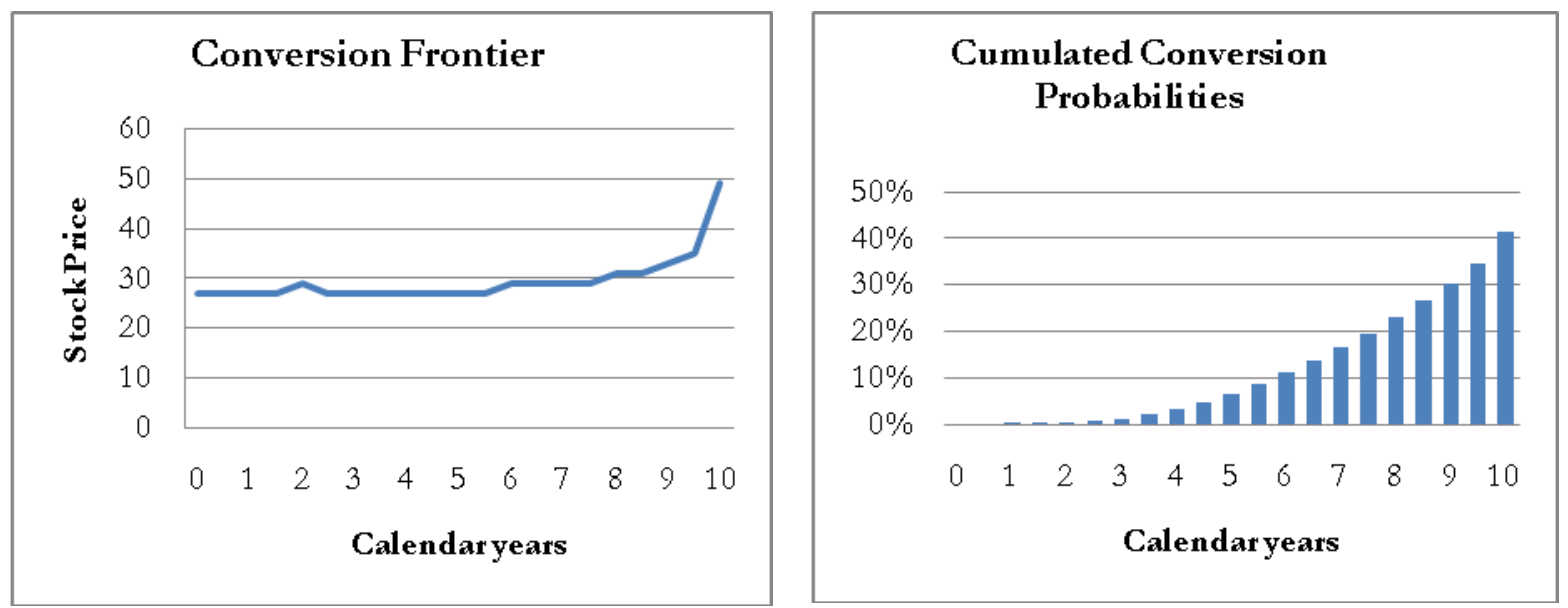

\footnotetext{
${ }^{61}$ Note that in year 10, the only conversion time would be the day before maturity (it then maximizes the possible non-payment of the total coupon). On that day, the conversion price could even be $\$ 51.61$. The issuer then has the choice between issuing two shares which are worth $\$ 103.22$, and thus avoid paying a semi-annual coupon of $\$ 3.22$ and possibly the nominal value of $\$ 100$ the day after. Since conversion times are discrete, Bermudan options ought to be considered instead of American Options. To smooth out these effects driven by the discrete timing of coupon payments the CAB could be structured to allow for a quarterly rather than a semi-annual coupon payment.
} 
Annex 3: Figures on Minimum regulatory capital requirements; Cumulative losses relative to capital requirements for four major banks; and capital ratios for 'crisis' and 'no crisis' banks.

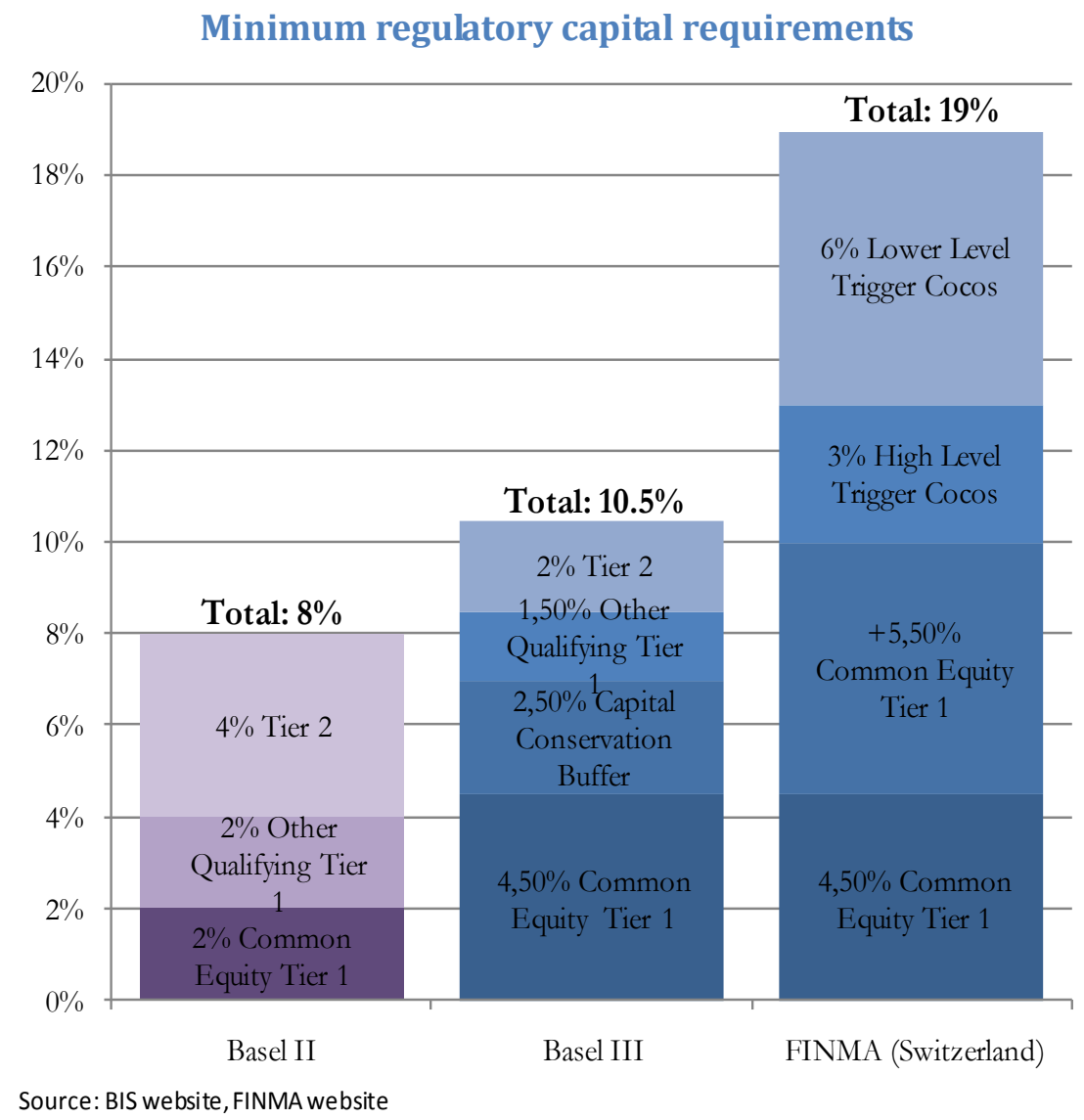

Losses on trading book relative to capital

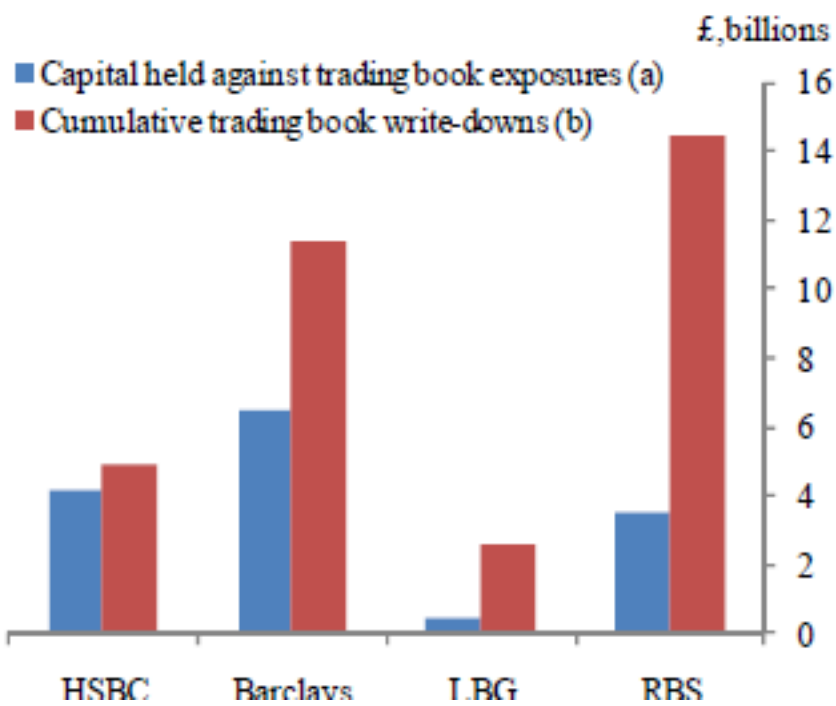

Source: Bank of England, A. Haldane
Capital ratios for 'crisis' and 'no crisis' banks

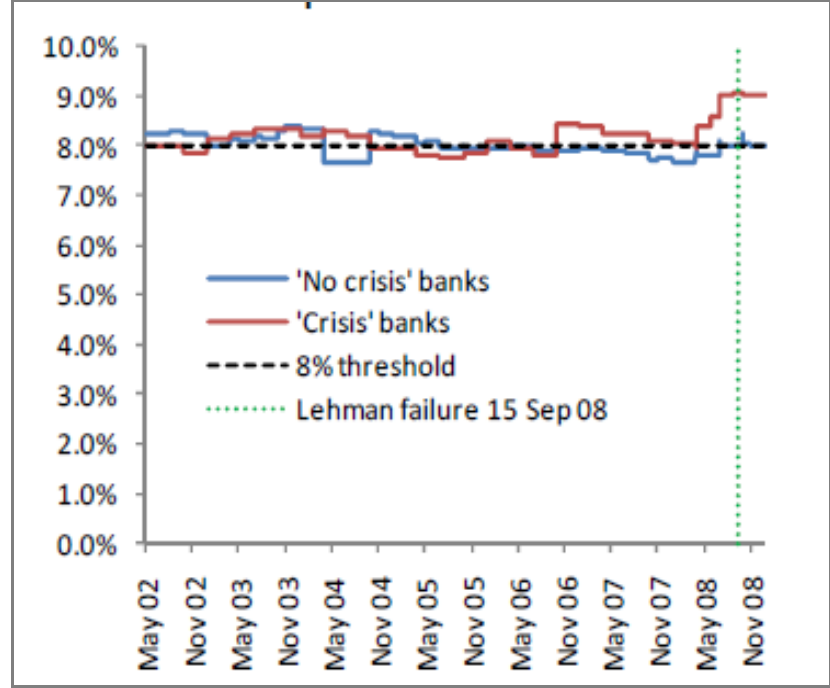

Source: Bank of England, A. Haldane 


\section{Losses on trading book relative to capital requirements}

(a) As of end-2007. Capital charges against trading book exposures are calculated as the the sum of market risk and counterparty credit risk RWAs, multiplied by $8 \%$. This might overestimate the amount of capital banks hold against their regulatory trading books as some market risk and counterparty credit risk capital charges relate to positions booked in the banking book.

(b) Cumulative between 2007 H2 and 2009 H1. Includes writedowns due to mark-to-market adjustments where details are disclosed by firms. Not all these positions will necessarily be included in the regulatory trading book.

\section{Capital ratios for 'crisis' and 'no crisis' banks}

(a) "Crisis" banks are a set of major financial institutions which in autumn 2008 either failed, required government capital or were taken over in distressed circumstances. These are RBS, HBOS, Lloyds TSB, Bradford \& Bingley, Alliance \& Leicester, Citigroup, Washington Mutual, Wachovia, Merrill Lynch, Freddie Mac, Fannie Mae, Goldman Sachs, ING Group, Dexia and Commerzbank. The chart shows an unweighted average for those institutions in the sample for which data are available on the given day.

(b) The "no crisis" institutions are HSBC, Barclays, Wells Fargo, JP Morgan, Santander, BNP Paribas, Deutsche Bank, Crédit Agricole, Société Générale, BBVA, Banco Popular, Banco Sabadell, Unicredit, Banca Popolare di Milano, Royal Bank of Canada, National Australia Bank, Commonwealth Bank of Australia and ANZ Banking Group. The chart shows an unweighted average for those banks in the sample for which data are available on the given day.

(c) The dotted black line is a suggested trigger level for contingent capital calibrated by minimising a loss function which takes into account both Type I and Type II errors. Type I error is the probability that conversion occurs despite capital not being required. Type II error is the event that conversion does not occur despite capital being required. The loss function places greater weight on Type II errors. Note that the loss function takes into account the full range of banks, not just the average score for each set. 
Annex 4 List of financial assets purchased by SWFs during the crisis

\begin{tabular}{|l|l|c|c|l|}
\hline Company & Investor & \%Stake & $\begin{array}{l}\text { Investment Value } \\
\text { in US\$ Millions }\end{array}$ & Security Type \\
\hline Citigroup & $\begin{array}{l}\text { Abu Dhabi Investment } \\
\text { Authority }\end{array}$ & 4.9 & 7,500 & New convertible units \\
\hline Citigroup & $\begin{array}{l}\text { Government of } \\
\text { Singapore Investment } \\
\text { Corp }\end{array}$ & 3.7 & 6,880 & New convertible units \\
\hline Citigroup & $\begin{array}{l}\text { Kuwait Investment } \\
\text { Authority }\end{array}$ & 1.6 & 3,000 & New convertible units \\
\hline Merrill Lynch & $\begin{array}{l}\text { Kuwait Investment } \\
\text { Authority }\end{array}$ & 3.0 & 2,000 & New convertible units \\
\hline Merrill Lynch & $\begin{array}{l}\text { Korea Investment } \\
\text { Corporation }\end{array}$ & 3.0 & 2,000 & New convertible units \\
\hline Merrill Lynch & Temasek Holdings & 9.4 & 4,400 & New common stock \\
\hline Morgan Stanley & China Investment Corp & 9.9 & 5,000 & New convertible units \\
\hline Barclays PLC & Temasek Holdings & 1.8 & 2,005 & Common stock \\
\hline Credit Suisse & $\begin{array}{l}\text { Qatar Investment } \\
\text { Authority }\end{array}$ & 1.0 & 603 & Common stock \\
\hline UBS & $\begin{array}{l}\text { Government of } \\
\text { Singapore Investment } \\
\text { Corp }\end{array}$ & 9.8 & 9,750 & New convertible units \\
\hline UBS & $\begin{array}{l}\text { Saudi Arabian Monetary } \\
\text { Agency }\end{array}$ & 2.0 & 1,800 & New convertible units \\
\hline Total capital infusions from Sovereign Wealth Funds $\$ \mathbf{4 4 , 9 3 8}$ & \\
\hline
\end{tabular}

